\title{
Recent Advances in Cell-Based Therapies for Ischemic Stroke
}

\author{
Satoshi Suda ${ }^{1, * \mathbb{C}}$, Chikako Nito $^{1}$, Shoji Yokobori ${ }^{2}$, Yuki Sakamoto ${ }^{1}$, Masataka Nakajima ${ }^{1}$, \\ Kota Sowa ${ }^{1}$, Hirofumi Obinata ${ }^{2}$, Kazuma Sasaki ${ }^{2}$, Sean I. Savitz ${ }^{3}$ and Kazumi Kimura ${ }^{1}$ \\ 1 Department of Neurology, Nippon Medical School, Tokyo 113-8602, Japan; cnito@nms.ac.jp (C.N.); \\ yuki-sakamoto@nms.ac.jp (Y.S.); masa-nakajima@nms.ac.jp (M.N.); 5058-ksowa@nms.ac.jp (K.S.); \\ k-kimura@nms.ac.jp (K.K.) \\ 2 Department of Emergency and Critical Care Medicine, Graduate School of Medicine, Nippon Medical \\ School, Tokyo 113-8602, Japan; shoji@nms.ac.jp (S.Y.); haj11570@gmail.com (H.O.); k-sasaki@nms.ac.jp (K.S.) \\ 3 Institute for Stroke and Cerebrovascular Disease, UTHealth, Houston, TX 77030, USA; \\ sean.i.savitz@uth.tmc.edu \\ * Correspondence: suda-sa@nms.ac.jp; Tel.: +81-3-3822-2131; Fax: +81-3-3822-4865
}

Received: 28 August 2020; Accepted: 10 September 2020; Published: 14 September 2020

\begin{abstract}
Stroke is the most prevalent cardiovascular disease worldwide, and is still one of the leading causes of death and disability. Stem cell-based therapy is actively being investigated as a new potential treatment for certain neurological disorders, including stroke. Various types of cells, including bone marrow mononuclear cells, bone marrow mesenchymal stem cells, dental pulp stem cells, neural stem cells, inducible pluripotent stem cells, and genetically modified stem cells have been found to improve neurological outcomes in animal models of stroke, and there are some ongoing clinical trials assessing their efficacy in humans. In this review, we aim to summarize the recent advances in cell-based therapies to treat stroke.
\end{abstract}

Keywords: angiogenesis; clinical trial; inflammation; neurogenesis; stem cell; stroke

\section{Introduction}

Although early interventions to treat damage caused by reperfusion such as intravenous thrombolysis and endovascular revascularization have shown significant benefits in stroke patients, stroke remains a leading cause of long-term disability worldwide. Therefore, stroke is associated with socioeconomic problems resulting from factors such as increased family burden and medical costs. Experimental laboratory results of stem cell-based therapy using different cell types have been promising, and some clinical trials are beginning to prove the safety and efficacy of this intervention [1-8]. In this review, we aim to summarize the studies of bone marrow mononuclear cells (MNCs), bone marrow mesenchymal stem (BMSCs), dental pulp stem cells (DPSCs), neural stem cells (NSCs), induced pluripotent stem cells (iPSCs), and genetically modified stem cells used for stem cell therapy, including their mechanisms of action and the beneficial effects following stroke in animal models and human studies.

\section{Bone Marrow Mononuclear Cells}

Bone marrow MNCs include a population of monocytes, lymphocytes, mesenchymal and hematopoietic stem cells, and hematopoietic and endothelial progenitor cells [9]. Stem cells such as BMSCs and iPSCs require a period of cell culture before transplantation, whereas MNCs can be collected autologously just prior to administration, which could be advantageous in acute clinical care settings compared with other cell sources. 


\subsection{Protective Mechanisms of Bone Marrow Mononuclear Cells against Stroke}

The experimental rationale for the use of MNCs in stroke therapy includes a number of mechanisms of action, such as the modulation of local and systemic inflammation, promotion of angiogenesis and endogenous neurogenesis, differentiation into cell types that facilitate cellular repair processes, and secretion of neurotrophic factors from the acute phase to the chronic phase after stroke [10-12] (Figure 1) (Table 1). The main mechanisms are considered to be angiogenesis and a reduction of endothelial damage.

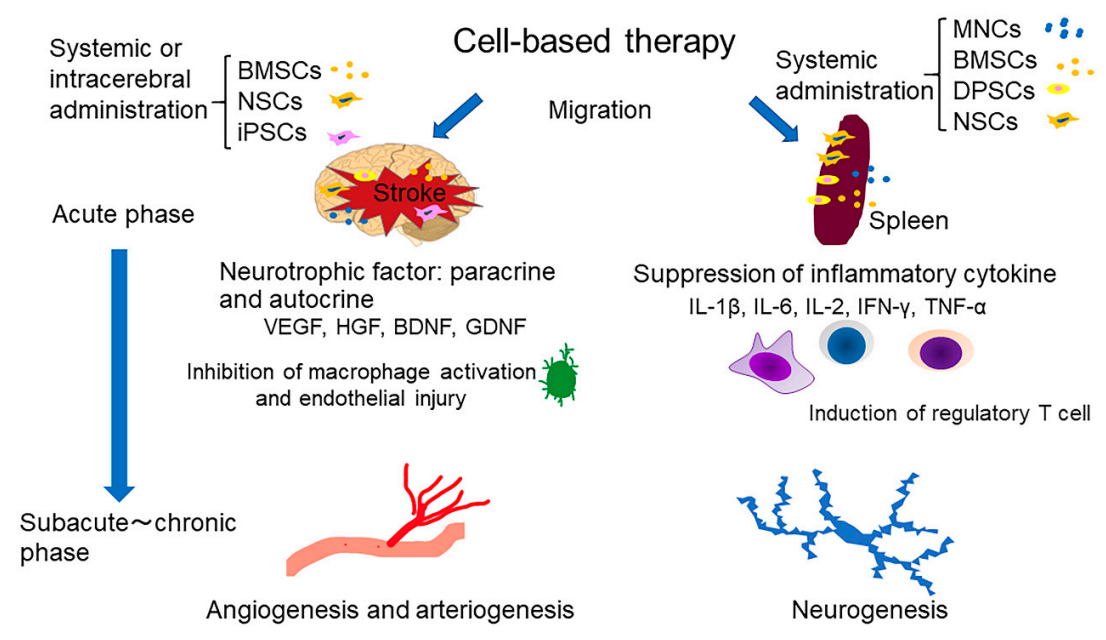

Figure 1. Overview of proposed mechanisms of cell-based stroke therapies. Engrafted therapeutic cells exert neuro- and vaso-protective effects through secretion of various growth factors and systemic inflammation modulation. MNCs, marrow mononuclear cells, BMSCs, bone marrow mesenchymal stem cells; DPSCs, dental pulp stem cells; NSCs, neural stem cells; iPSCs, induced pluripotent stem cells; VEGF, vascular endothelial growth factor; HGF, hepatocyte growth factor; BDNF, brain-derived neurotrophic factor; GDNF, glial cell-derived neurotrophic factor; IL-1 $\beta$, interleukin 1 beta; IL-6, interleukin 6; IL-2, interleukin 2; IFN- $\gamma$, interferon gamma; TNF- $\alpha$, tumor necrosis factor alpha.

MNCs increase vascular density and blood flow in patients with various ischemic disorders, such as cardiovascular disease, peripheral arterial disease, and diabetic foot pathologies [13-18]. Initial studies indicated that differentiation of hematopoietic stem cells into endothelial cells (ECs) was the major contributory mechanism of recovery. Subpopulations of MNCs, such as CD $34^{+} / \mathrm{M}^{-}$-cadherin ${ }^{+}$ cells, can promote angiogenesis and arteriogenesis by differentiating into smooth muscle cells (SMCs) and ECs in ischemic hindlimbs of rodents $[19,20]$. Wang et al. reported that transplanted MNCs had the capacity to differentiate into SMCs and ECs after permanent middle cerebral artery occlusion (MCAO) in rats $[20,21]$. These findings illustrate that MNCs are involved in angiogenesis and arteriogenesis, which may contribute to improved blood flow restoration in ischemic tissue. In a mouse model of bilateral common carotid artery stenosis, MNC treatment induced an increase in cerebral blood flow (CBF) through the upregulation of Ser1177 phosphorylation and increased endothelial nitric oxide synthase levels beginning in the early phase after stoke, as well as subsequent restoration of endogenous responses in the later phase, including angiogenesis [22]. However, in that study, the authors observed benefits from MNC treatment despite a lack of evidence of direct structural incorporation of donor MNCs into ECs. Also, subsequent studies showed that transdifferentiation of grafted MNCs into an EC phenotype was only rarely observed $(<1 \%)[23,24]$. Very recently, Taguchi et al. demonstrated that MNCs accelerate vascular endothelial growth factor (VEGF) uptake into ECs and suppress autophagy through gap junction-mediated cell-cell interactions [25]. These findings provided evidence of a novel mechanism through which a prominent gap junction-mediated signaling pathway activates angiogenesis and supports the survival of injured ECs after ischemia. 
Table 1. Experimental study for the bone marrow mononuclear cells (MNCs) transplantation into ischemic brain injury in animal model.

\begin{tabular}{|c|c|c|c|c|c|c|c|}
\hline Authors, Year & Cell Type & Number of Cells & Animal Model & Delivery Method & Delivery Timing & Results & Reference \\
\hline Okinaka, Y. et al. 2019 & Human clot-free MNCs & $1 \times 10^{5}$ & Mice permanent $\mathrm{MCAO}$ & Intravenous & $48 \mathrm{~h}$ post-ischemia induction & Brain atrophy $\downarrow$ & [26] \\
\hline Yang, B. et al. 2017 & Rat MNCs & $1 \times 10^{7}$ & $\begin{array}{l}\text { Rat embolic stroke model } \\
\text { with recombinant tissue } \\
\text { plasminogen activator }\end{array}$ & $\begin{array}{l}\text { Intravenous } \\
\text { (femoral vein) }\end{array}$ & $3 \mathrm{~h}$ post-ischemia induction & $\begin{array}{c}\text { Infarct volume } \rightarrow \\
\text { Hemorrhage transformation } \downarrow \\
\text { BBB permeability } \downarrow \\
\text { Inflammation modulation }\end{array}$ & [27] \\
\hline Li, Y. et al. 2016 & $\begin{array}{l}\text { MNCs from } \\
\text { 5-fluorouracil } \\
\text { pre-treated rats }\end{array}$ & $1 \times 10^{7}$ & Rat MCAO (120 min) & $\begin{array}{l}\text { Intravenous } \\
\text { (tail vein) }\end{array}$ & $24 \mathrm{~h}$ post-ischemia induction & $\begin{array}{l}\text { Infarct volume } \downarrow \\
\text { Neurological outcome } \uparrow \\
\text { growth factors } \uparrow\end{array}$ & [28] \\
\hline Suda, S. et al. 2015 & Rat MNCs & $1 \times 10^{7}$ & Rat ICH model & $\begin{array}{l}\text { Intravenous } \\
\text { (tail vein) }\end{array}$ & $24 \mathrm{~h}$ post-ICH induction & $\begin{array}{c}\text { Brain edema } \downarrow \\
\text { Brain atrophy } \downarrow \\
\text { Cognitive functional recovery } \\
\uparrow \text { Inflammation modulation } \\
\text { Angiogenesis } \uparrow\end{array}$ & [10] \\
\hline Yang, B. et al. 2013 & Rat MNCs & $1 \times 10^{7}$ & Rat MCAO (90 min) & $\begin{array}{l}\text { Intravenous } \\
\quad \text { and } \\
\text { intra-arterial }\end{array}$ & 24h post-ischemia induction & $\begin{array}{c}\text { Neurological outcome } \uparrow \\
\text { Inflammation modulation } \\
\text { Neurogenesis } \uparrow\end{array}$ & [29] \\
\hline Nakano-Doi, A. et al. 2010 & Mice MNCs & $1 \times 10^{6}$ & Mice permanent MCAO & $\begin{array}{l}\text { Intravenous } \\
\text { (tail vein) }\end{array}$ & $24 \mathrm{~h}$ post-ischemia & $\begin{array}{c}\text { Neurological outcome } \uparrow \\
\text { Cerebral blood flow } \uparrow \\
\text { Endothelial proliferation } \uparrow \\
\text { Proliferation of neural } \\
\text { stem/progenitor cells } \uparrow\end{array}$ & [30] \\
\hline
\end{tabular}

ICH, intracerebral hemorrhage; MCAO, middle cerebral artery occlusion. “ $\uparrow ”($ means increase), “ $\downarrow$ ” (means decrease), and “ $\rightarrow$ "(means no change). 


\subsection{Clinical Studies of Bone Marrow Mononuclear Cells Efficacy Following a Stroke}

Savitz et al. previously reported that intravenous infusion of autologous MNCs within 24-72 $\mathrm{h}$ after a stroke might be effective compared with a control group of age- and National Institutes of Health Stroke Scale (NIHSS) score-matched historical stroke patients [31]. In addition, Taguchi et al. reported that intravenous infusion of autologous MNCs with 7-10 days of the onset of stroke was a safe and feasible therapy that led to improved functional recovery and increased CBF and metabolism in stroke patients with severe ischemia (NIHSS score $\geq 10$ on day 7 post-stroke) [32]. On the other hand, a phase II, multicenter, randomized clinical trial demonstrated that intravenous infusion of autologous MNCs at a median of 18.5 days after stroke onset was safe, but they observed no beneficial effect of treatment on stroke outcomes [33]. These clinical results indicate that earlier transplantation of MNCs soon after stroke onset may be more efficacious in promoting recovery. Since MNCs offer the particular advantage of acute and autologous transplantability, age, sex, and underlying comorbidities might influence both the patients' susceptibility to and the functionality of MNC grafts, though more research is needed to identify the impact of these factors on the efficacy of MNC transplantation for stroke treatment [34].

\section{Bone Marrow Mesenchymal Stem Cells}

BMSCs have self-renewal potential. These cells express markers of mesenchymal cells or ECs (CD105, CD73, and CD90), as well as adhesion molecules (CD106, CD166, and CD29), but not hematopoietic stem cell markers (CD11, CD14, CD34, CD45, CD79, CD19, and human leukocyte antigen DR isotype [HLA-DR]) $[35,36]$. BMSCs are easily cultured in vitro, have weak immunogenicity and a good safety profile, and have been considered to be ideal seed cells in the treatment of ischemic stroke [37].

\subsection{Protective Mechanisms of Bone Marrow Mesenchymal Stem Cells against Stroke}

BMSCs have been widely investigated in experimental stroke models (Table 2). Studies have shown that BMSCs have the ability to differentiate into neuronal cells in vitro in coculture or differentiation medium. BMSCs can also influence the microenvironment at an injury site through the secretion of anti-inflammatory factors or by decreasing interleukin 1 beta (IL-1 $\beta$ ), interleukin 6 (IL-6), and tumor necrosis factor alpha (TNF- $\alpha$ ) levels. They may also induce the secretion of antiapoptotic molecules and trophic factors that promote angiogenesis, immunomodulation, including inhibition of T-cell proliferation, promotion of regulatory T cell (Treg) function, and diminishment of IL-23/IL-17 expression, and increased axonal growth [37-41].

\subsection{Efficacy and Safety of Bone Marrow Mesenchymal Stem Cells in Clinical Trials}

In a prospective, randomized study of 30 patients with severe stroke, Bang et al. showed that BMSCs improved the modified Rankin scale (mRS) and Barthel index scores up to a year after stroke [1]. Serial evaluations showed no adverse cell-related, serological, or imaging-defined effects. Similarly, Honmou et al. reported that intravenous infusion of autologous BMSCs expanded in human serum into 12 subjects 36-133 days post-stroke did not result in any significant adverse events [4]. 
Table 2. Experimental study for the bone marrow mesenchymal stem cell (BMSCs) transplantation into ischemic brain injury in animal model.

\begin{tabular}{|c|c|c|c|c|c|c|c|}
\hline Authors, Year & Cell Type & Number of Cells & Animal Model & Delivery Method & Delivery Timing & Results & Reference \\
\hline Tobin, M.K. et al. 2020 & $\begin{array}{c}\text { Interferon- } \gamma \text {-activated } \\
\text { BMSCs }\end{array}$ & $5 \times 10^{6} / \mathrm{kg}$ & Rat MCAO (90 min) & $\begin{array}{c}\text { Intravenous } \\
\text { (retro-orbital sinus) }\end{array}$ & $\begin{array}{l}4.5 \mathrm{~h} \text { post-ischemia } \\
\text { induction }\end{array}$ & $\begin{array}{c}\text { Infarct volume } \downarrow \\
\text { Neurological outcome } \uparrow \\
\text { Cerebral blood flow } \uparrow \\
\text { Oligodendrogenesis } \uparrow \\
\text { Inflammation modulation }\end{array}$ & [42] \\
\hline Nakajima, M. et al. 2017 & $\begin{array}{c}\text { Human BMSCs } \\
\text { Interleukin-10-transfected } \\
\text { BMSCs }\end{array}$ & $1 \times 10^{6}$ & Rat MCAO (90 min) & Intravenous & $\begin{array}{l}0 \text { or } 3 \mathrm{~h} \text { after ischemia } \\
\text { reperfusion }\end{array}$ & $\begin{array}{c}\text { Infarct volume } \downarrow \\
\text { Neurological outcome } \uparrow \\
\text { Inflammation modulation }\end{array}$ & [43] \\
\hline Kawabori, M. et al. 2016 & Rat BMSCs & $1 \times 10^{5}$ or $1 \times 10^{6}$ & Rat permanent MCAO & Ipsilateral striatum & $\begin{array}{c}1 \text { or } 4 \text { weeks } \\
\text { post-ischemia induction }\end{array}$ & $\begin{array}{l}\text { Neurological outcome } \uparrow \\
\text { Differentiation of MSCs }\end{array}$ & [44] \\
\hline Toyoshima, A. et al. 2015 & Rat BMSCs & $1 \times 10^{6}$ & Rat MCAO (90 min) & Intra-arterial & $\begin{array}{c}1,6,24,48 \mathrm{~h} \text { after ischemia } \\
\text { induction }\end{array}$ & $\begin{array}{c}\text { Infarct volume } \downarrow \\
\text { Neurological outcome } \uparrow \\
\text { neurotrophic factor } \uparrow\end{array}$ & [45] \\
\hline Nakazaki, M. et al. 2015 & Rat BMSCs & $1 \times 10^{7}$ & $\begin{array}{c}\text { Spontaneously } \\
\text { hypertensive rat } \\
\text { (stroke-prone) } \\
\text { (SHRSP) model }\end{array}$ & Intravenous & 21 weeks of age & $\begin{array}{c}\text { Disruption of blood brain barrier } \downarrow \\
\text { Brain atrophy } \downarrow \\
\text { Amyloid } \beta \text { accumulation } \downarrow \\
\text { Cognitive functional recovery } \uparrow\end{array}$ & [46] \\
\hline Wang, L.Q. et al. 2014 & Rat BMSCs & $1 \times 10^{4 \sim 7}$ & Rat permanent MCAO & $\begin{array}{l}\text { Intravenous } \\
\text { (tail vein) }\end{array}$ & $\begin{array}{l}3 \text { and } 24 \mathrm{~h} \text { and } 7 \text { days } \\
\text { post-ischemia induction }\end{array}$ & $\begin{array}{c}\text { Infarct volume } \downarrow \\
\text { Neurological outcome } \uparrow \\
\text { Inflammation modulation }\end{array}$ & [47] \\
\hline
\end{tabular}

MCAO, middle cerebral artery occlusion. " " (means increase) and “ $\downarrow$ ” (means decrease). 
The SanBio study assessed the use of SB623 cells, which are allogenic modified BMSCs transiently transfected with the human Notch-1 intracellular domain, in a two-year, single-arm, open-label, uncontrolled study of 18 patients in a stable chronic phase after stroke (6-60 months post-stroke) [48]. SB623 cells were injected, stereotactically, into the infarct area and the subjects were followed for 24 months. Significant improvements were observed based on the European Stroke Scale score, the NIHSS score, Fugl-Meyer total score, and Fugl-Meyer motor score; however, there was no statistically significant improvement of the subjects' mRS scores. The efficacy of the treatment plateaued within one year, without decreasing thereafter [48]. Recently, Savitz et al. conducted a randomized, sham controlled, phase II trial in which subjects received intracarotid delivery of aldehyde dehydrogenase (ALDH)-bright cells (13 and 19 days poststroke) isolated from the bone marrow of patients who had recently experienced an ischemic middle cerebral artery stroke [6]. Although the study provided a framework for conducting randomized, sham-controlled trials involving intracarotid administration of autologous, sorted BMSCs in patients with a recent stroke, there were no significant differences between the groups based on any of the efficacy measures (mRS at 90 days, as wells as disability assessed by Barthel index scores, quality of life based on European Quality of Life5 Dimension (EQ-5D) scores, and rehabilitation utilization at one year).

Unlike the studies described above, the RAINBOW trial was a first-in-human trial to use superparamagnetic iron oxide-labelled BMSCs to treat patients following a subacute ischemic stroke. Preliminary results indicated that intracerebral transplantation of autologous BMSCs was safe and well tolerated. Moreover, it is expected that bio-imaging techniques could help clarify the therapeutic mechanisms of action [7,49]. Taken together, these studies support the safety of BMSCs or BM-derived cells for transplantation in patients with ischemic stroke, although the therapeutic efficacy remains controversial. Further studies are needed to identify the optimal transplantation protocol for routine clinical applications, including the concentration of cells, the timing, the route of administration, patient selection criteria (age, stroke subtype, and location of damage), and combination therapies.

\section{Dental Pulp Stem Cells}

Human DPSCs are the neural crest-derived stem cells residing within the perivascular niches of the dental pulp [50] and are an attractive cell source because they can be easily obtained as medical waste without ethical or logistical complications [51]. As human DPSCs originate from the neuronal lineage, they are considered a particularly promising strategy for treatment of severe neurological disorders. DPSC isolation from extracted teeth is easily performed and less invasive than the isolation of BMSCs. DPSCs express a variety of cell surface markers similar to BMSCs, such as CD29, CD90, and CD105, but they do not express hematopoietic markers, such as CD34 and CD45 [52]. Human DPSCs also exhibit approximately three times higher proliferation in vitro than human BMSCs [53]; they are multipotent and can differentiate into muscle, cartilage, bone, and other cell types [54]. In addition, DPSCs have also been shown to exert potent immune-modulatory properties through the inhibition of activated T-cell responses [51]. The immunosuppressive properties of DPSCs make them attractive for use in allogeneic transplantation. The neurotrophic factors secreted by DPSCs are involved in processes mediated by nerve growth factor (NGF), neurotrophin-3, brain-derived neurotrophic factor (BDNF), glial cell-derived neurotropic factor (GDNF), and vascular endothelial growth factor (VEGF); these molecules promote neuronal survival, cellular proliferation, differentiation, and migration [55]. DPSCs exhibit properties of both neural stem cells and mesenchymal stem cells (MSCs), with reported utility for the treatment of cerebral ischemia [56-58]. Several studies have shown that DPSC transplantation is associated with neuroprotective effects and enhances functional recovery after cerebral ischemia in vivo (Table 1) [59-64] (Table 3); however, more basic science studies are needed to confirm a safe and efficacious method for DPSC transplantation during the acute phase after ischemic stroke. 
Table 3. Experimental study for the dental pulp stem cells (DPSCs) transplantation into ischemic brain injury in animal model.

\begin{tabular}{|c|c|c|c|c|c|c|c|}
\hline Authors, Year & Cell Type & Number of Cells & Animal Model & Delivery Method & Delivery Timing & Results & Reference \\
\hline Leong, W.K. et al. 2012 & Human DPSCs & $6 \times 10^{5}$ & Rat MCAO (2 h) & $\begin{array}{l}\text { Intracerebral (striatum } \\
\text { and cortex) }\end{array}$ & $\begin{array}{l}24 \mathrm{~h} \text { post-ischemia } \\
\text { induction }\end{array}$ & $\begin{array}{l}\text { Differentiation into astrocytes } \\
\text { Neuroprotection } \\
\text { Functional outcomes } \uparrow\end{array}$ & [60] \\
\hline Song, M. et al. 2017 & Human DPSCs & $4 \times 10^{6}$ & Rat MCAO (2 h) & $\begin{array}{l}\text { Intravenous } \\
\text { (tail vein) }\end{array}$ & $\begin{array}{l}24 \mathrm{~h} \text { post-ischemia } \\
\text { induction }\end{array}$ & $\begin{array}{c}\text { Infarct volume } \downarrow \\
\text { Neurological outcome } \uparrow \\
\text { Differentiation into astrocytes and neuron-like cells } \\
\text { Promoted angiogenesis and inhibited astrocytes }\end{array}$ & [61] \\
\hline Kumasaka, A. et al. 2017 & $\begin{array}{l}\text { Rat DPSCs (dental } \\
\text { pulp-derived } \\
\text { neurospheres) }\end{array}$ & $1 \times 10^{6}$ & $\begin{array}{l}\text { Rat severe forebrain } \\
\text { ischemia (11 } \mathrm{min})\end{array}$ & $\begin{array}{l}\text { Intravenous } \\
\text { (tail vein) }\end{array}$ & $\begin{array}{l}3 \mathrm{~h} \text { post-ischemia } \\
\text { induction }\end{array}$ & $\begin{array}{c}\text { Survival rate } \uparrow \\
\text { Cognitive functional recovery } \uparrow \text { Reduced the dead } \\
\text { neurons of hippocampus CA1 }\end{array}$ & [59] \\
\hline Nito, C. et al. 2018 & Human DPSCs & $1 \times 10^{6}$ & Rat MCAO (90 min) & $\begin{array}{l}\text { Intravenous } \\
\text { (tail vein) }\end{array}$ & $\begin{array}{l}\text { Immediately or } 3 \mathrm{~h} \\
\text { post-ischemia }\end{array}$ & $\begin{array}{c}\text { Infarct volume } \downarrow \\
\text { Neurological outcome } \uparrow \\
\text { Inflammation modulation }\end{array}$ & [62] \\
\hline Sowa, K. et al. 2018 & $\begin{array}{c}\text { Human DPSCs } \\
\text { HGF-transfected DPSCs }\end{array}$ & $1 \times 10^{6}$ & Rat MCAO (90 min) & $\begin{array}{l}\text { Intravenous } \\
\text { (tail vein) }\end{array}$ & $\begin{array}{l}\text { Immediately } \\
\text { post-ischemia }\end{array}$ & $\begin{array}{c}\text { Infarct volume } \downarrow \\
\text { Neurological outcome } \uparrow \\
\text { Inflammation modulation } \\
\text { Promoted angiogenesis }\end{array}$ & [63] \\
\hline Zhang, X. et al. 2018 & Rat DPSCs & $1 \times 10^{6}$ & Rat MCAO (2 h) & $\begin{array}{l}\text { Intravenous } \\
\text { (tail vein) }\end{array}$ & $24 \mathrm{~h}$ post-ischemia & $\begin{array}{c}\text { Infarct volume } \downarrow \\
\text { Edema volume } \downarrow \\
\text { Differentiation into neuron-like cells }\end{array}$ & [64] \\
\hline
\end{tabular}

HGF, hepatocyte growth factor; MCAO, middle cerebral artery occlusion. “ $\uparrow$ " (means increase) and “ $\downarrow$ ” (means decrease). 


\subsection{Protective Effects of Dental Pulp Stem Cells after Ischemic Stroke In Vivo}

Multipotent stem cells, such as DPSCs, have limited differentiation potential, which makes them potentially safer for clinical use, with no authenticated risk of tumor formation $[57,65,66]$. Recent studies have also shown that engrafted human DPSCs can survive in damaged central nervous system (CNS) tissue and exert immunomodulatory effects by upregulating anti-inflammatory cytokines and attenuating pro-inflammatory cytokines secreted from activated microglia and macrophages in murine xenogenic transplantation models without the use of immunosuppressive drugs [67-69]. The mechanisms of action of exogenous DPSC treatment in various in vivo experiments have been attributed to their paracrine effects [70], which are mediated by the release of secreted factors, cytokines, chemokines, and growth and trophic factors, including the stromal cell-derived factor-1, NGF, BDNF, GDNF, and VEGF [71,72]. The autocrine and paracrine effects of DPSCs have been proposed to be responsible for improving the microenvironment of host cells and for enhancing endogenous restorative processes following injury or disease. Indeed, stem cell transplantation is also regarded as a cell-based cytokine therapy [73]. For example, IL-10, which is produced by regulatory T lymphocytes, reduces pro-inflammatory cytokine production and the neurotoxicity associated with TNF- $\alpha$ and interferon gamma (IFN- $\gamma$ ) signaling in ischemic brain injury [74]. DPSC transplantation suppresses TNF- $\alpha$ and IL-1 $\beta$ levels, which are markers of systemic inflammation in both the brain and serum, $72 \mathrm{~h}$ after reperfusion injury [69]. Similarly, VEGF expressed in macrophages, neurons, glia, and vascular ECs promotes angiogenesis in the ischemic brain during tissue repair [75].

A previous study has shown that human DPSCs could potentially differentiate into functional neural progenitor cells or neurons, which can integrate with other brain tissues [76]. Other studies showed that transplanted DPSCs were able to migrate to the boundaries of ischemic areas, differentiate into neuron- and astrocyte-like cells in the rat brain [61], and express neuronal and NSC markers such as $\beta$ III tubulin, doublecortin, nestin, and neurofilament [64]. However, very few DPSCs were able to survive in the ischemic brain, and most migrated to the peri-infarct areas where they differentiated mostly into astrocytes rather than neurons. Thus, the limited survival, differentiation, and integration of DPSC-derived cells into the ischemic lesion implies that functional improvements are more likely to be mediated through bystander effects rather than as a result of cell replacement and differentiation. Although the precise neuroprotective mechanisms associated with transplanted DPSCs remain unclear, they are likely related, at least in part, to anti-inflammatory and angiogenic factors.

The optimal route of transplanted stem cells has been investigated, with studies showing that intravascular delivery was the predominant route, followed by intracranial or intraventricular routes [77]. Intra-arterial injection, which facilitates higher levels of cell engraftment in the target organ, may increase the risk for the development of a microembolism after cell transplantation [78]. This means that the incidence of MSC-induced vascular obstructions and stroke after intra-carotid injection is closely related to the size of the cells [79], and several studies have reported that the intravenous administration of human DPSCs decreased ischemic damage and promoted functional improvement in a rodent model of focal cerebral ischemia (Table 1). Intravenous administration of DPSCs can reduce the risk of arterial microembolism since the cell sizes are similar to those of MSC populations; however it is important to consider the filtering effect as the cells pass through the lungs after systemic delivery.

\subsection{Clinical Studies of Dental Pulp Stem Cells Administration after a Stroke}

Intravenous administration of DPSCs is less invasive than intracerebral or intraventricular transplantation, thereby reducing trauma to stroke patients. Moreover, systemic delivery of the cells allows for easier transmigration through the blood brain barrier (BBB) to the ischemic hemisphere, and it is an effective and safe procedure for acute stroke patients $[4,47,80]$. Clinical investigations involving intravenous injection of human allogenic DPSCs have already begun in Japan. JTR-161 is a first-in-human, randomized, double-blind, placebo-controlled, multicenter clinical trial to evaluate the safety and efficacy of DPSC administration in patients with ischemic stroke. This study was designed 
in accordance with good manufacturing practice by JCR Pharmaceuticals Co., Ltd. and consists of three cohorts. The DPSCs used in the study are diluted in $100 \mathrm{~mL}$ of saline for a single intravenous administration after stroke onset. Patients are recruited from 29 stroke centers in Japan between December 2018 and July 2021.

\section{Neural Stem Cells}

In 1962, the possibility of neural proliferation was described in adult rats by Altman [81]. In 1992, Reynolds, Weiss, and colleagues isolated NSCs and propagated them in the presence of epidermal growth factor (EGF) for the first time to give rise to large cellular spheres that they termed "neurospheres" [82,83]. Neurons and glial cells are derived from common immature NSCs, which are defined as self-renewing and multipotent cells that can differentiate into neurons, astrocytes, and oligodendrocytes. NSCs have been found to exist not only in the developing brain but also in the mature mammalian brain. NSCs exist in at least two regions of the adult brain-the subventricular zone (SVZ) of the lateral ventricle and the subgranular zone (SGZ) of the hippocampus. NSCs in the SVZ mainly migrate along the rostral migratory stream to the olfactory bulb, whereas NSCs in the SGZ migrate to the granule cell layer where they finally differentiate into various neural cells and integrate into neuronal networks [84]. In addition, the human brain may contain another stem cell pool in the deep ventral region of the prefrontal cortex due to the highly developed prefrontal lobe [85].

NSCs can be derived from several sources, including embryonic stem cells and fetal tissue. Two main processes regulate the differentiation of NSCs, like self-regulation and exogenous signal regulation [86]. Self-regulation is controlled in the developmental period by several intrinsic and transcription factors. Activation of Notch-mediated signaling initiates the proliferation of NSCs, thereby increasing their numbers. In addition, the self-regulation of NSCs is controlled by other transcription factors or pathways, such as the Wnt and the Sonic hedgehog signaling pathways [87]. Regulation by exogenous signaling is also important for the differentiation of developing NSCs; NSCs originating from the same source can differentiate into different types of cells in the CNS based on the local microenvironment in brain tissue. This exogenous signal regulation of NSC proliferation, differentiation, and self-renewal is also mediated by several cytokines and neurological growth factors, including fibroblast growth factor (FGF) [88], EGF [89], BDNF [90], and PDGF [91] (Table 4). 
Table 4. Experimental study for the neural stem cells (NSCs) transplantation into ischemic brain injury in animal model.

\begin{tabular}{|c|c|c|c|c|c|}
\hline Authors, Year & Cell Type & Experimental Model & Procedure of Transplantation, Timing & Results & Reference \\
\hline Wang, G. et al. 2020 & $\begin{array}{l}\text { NSCs (transducted with circHIPK2 } \\
\text { siRNA) }\end{array}$ & Mice MCAO & Intracerebral, 7 days post-ischemia induction & $\begin{array}{c}\text { Neural differentiation } \uparrow \text { Neuronal plasticity in the } \\
\text { ischemic brain } \uparrow \\
\text { Long-lasting neuroprotection } \\
\text { Functional deficits } \downarrow\end{array}$ & [93] \\
\hline Kondori, B.J. et al. 2020 & NSCs isolated from rat SVZ & Rat MCAO & Intra-arterial, 1 day post -ischemia & Infarct size and volume $\downarrow$ Neurological outcome $\uparrow$ & [92] \\
\hline Kim et al. 2020 & $\begin{array}{l}\text { human neural stem cells (NSCs) } \\
\text { encoding gene of choline } \\
\text { acetyltransferase (F3.ChAT), an } \\
\text { acetylcholine-synthesizing enzyme }\end{array}$ & Rat MCAO & Intravenous, $2 \mathrm{~h}$ post-ischemia & $\begin{array}{c}\text { Infarction volume } \downarrow \\
\text { Cognitive dysfunction } \downarrow \text { Behavioral deficits } \downarrow\end{array}$ & [91] \\
\hline Tian et al. 2019 & $\begin{array}{l}\text { Leukemia inhibitory factor } \\
\text { (LIF)-transfected NSCs }\end{array}$ & Rat MCAO & Intravenous, $6 \mathrm{~h}$ post-ischemia & $\begin{array}{c}\text { Infarction volume } \downarrow \\
\text { Neurological recovery } \uparrow \\
\text { Glial cell regeneration } \uparrow \\
\text { White matter injury } \downarrow\end{array}$ & [90] \\
\hline George et al. 2017 & Electrically preconditioned hNPCs & Rat MCAO & Intracerebral, 7 days post-ischemia induction & Functional outcomes $\uparrow$ & [89] \\
\hline Hou et al. 2017 & NSCs & $\begin{array}{c}\text { Mice } \\
\text { photothromboticischemia } \\
\text { stroke model }\end{array}$ & Intracerebral, 2 days post-ischemia induction & $\begin{array}{c}\text { Infarct size and volume } \uparrow \text { Functional recovery } \downarrow \\
\text { Neurogenesis } \uparrow\end{array}$ & [88] \\
\hline Zhu et al. 2017 & NSCs (Noggin-transfected) & Rat MCAO & Intracerebral, 3 days post-ischemia induction & $\begin{array}{c}\text { Neurological scores } \uparrow \\
\text { Apoptotic neurons } \downarrow \\
\text { Neuronal morphological damage } \downarrow\end{array}$ & [87] \\
\hline Bacigaluppi et al. 2016 & Neural precursor cells & Mice MCAO & Intracerebral, 3 days post-MCAO & $\begin{array}{c}\text { Synaptic strength } \uparrow \\
\text { Functional recovery } \uparrow \\
\text { VEGF } \uparrow\end{array}$ & [86] \\
\hline Abeysinghe et al. 2015 & $\begin{array}{l}\text { Pre-differentiation of NSCs into } \\
\text { GABAergic neurons }\end{array}$ & Rat MCAO & Intracerebral, 7 days post-MCAO & $\begin{array}{c}\text { Motor function } \uparrow \\
\text { Proliferation } \uparrow \\
\text { Neurogenesis } \uparrow \\
\end{array}$ & [85] \\
\hline Yao et al. 2015 & Induced NSCs and NSCs & Rat MCAO & Intracerebral, 2 days post-MCAO & Intracerebral lesion size $\downarrow$ Functional recovery $\uparrow$ & [84] \\
\hline Cheng et al. 2015 & NSCs & Rat MCAO & Intravenous injection, 1 day post-MCAO & Functional recovery $\uparrow$ Neurogenesis $\uparrow$ & [83] \\
\hline Rosenblum et al. 2015 & $\begin{array}{l}\text { Brain-derived neurotrophic factor } \\
\text { pretreatment of human } \\
\text { embryo-derived NSCs }\end{array}$ & Mice hypoxia-ischemia model & $\begin{array}{l}\text { Intra-arterial injection, } 3 \mathrm{~d} \\
\text { post-hypoxia-ischemia }\end{array}$ & $\begin{array}{c}\text { Neuroprotection } \uparrow \\
\text { Survival } \uparrow \\
\text { Functional recovery } \uparrow\end{array}$ & [82] \\
\hline Song et al. 2015 & Ferumoxide-labeled hNSCs & Rat MCAO & Intravenous injection, 1 day post-MCAO & $\begin{array}{c}\text { Infarct volume } \downarrow \\
\text { Functional recovery } \uparrow \text { Neurogenesis } \uparrow\end{array}$ & [81] \\
\hline
\end{tabular}

MCAO: Middle cerebral artery occlusion. " $\uparrow$ " (means increase) and " $\downarrow$ " (means decrease). 


\subsection{Experimental Studies Investigating Neural Stem Cells Transplantation to Treat Stroke}

The discovery of NSCs provided a promising new therapy for the treatment of a variety of neurological diseases and injuries, such as Parkinson's disease, Huntington's disease, Alzheimer's disease, multiple sclerosis, amyotrophic lateral sclerosis, spinal cord injury, traumatic brain injury, and stroke, all of which are characterized by the failure of endogenous repair mechanisms in the CNS to restore damaged tissue and rescue lost functions [92,93]. As shown in Table 2, many studies have assessed NSC transplantation to treat ischemic brain injury in animal models. The initial hypotheses were based on the assumption that NSCs would replace lost neurons and restore connections in neuronal circuitry [94-106]. Indeed, analysis of graft-derived neuronal cells using immuno-electron microscopy and electrophysiological recording demonstrated increased connectivity, showing that NSCs could develop into functioning neurons to contribute to improved recovery from stroke and brain injury in rats $[107,108]$. Although transplanted NSCs are expected to differentiate into various neural cells rather than other stem cells, it remains unclear to what extent this contributes to functional recovery. The current understanding is that transplanted NSCs likely prevent neuronal apoptosis, exert immunomodulatory effects inside and outside the brain, increase endogenous neuronal regeneration and angiogenesis, and inhibit glial scar formation mainly via paracrine and autocrine secretion of various neurotrophic factors rather than differentiation [81-106,109,110] (Table 2).

\subsection{Clinical Studies Investigating Neural Stem Cells Transplantation to Treat Stroke}

NSC transplantation has been performed mainly as a treatment during the chronic phase post-stroke, which has as few therapeutic options as treatment during the acute phase. In the early 2000s, many studies investigated the use of NSCs for treatment during the chronic phase; however, there have been few completed clinical trials of cell-based therapy, and those that exists included small cohorts of patients with chronic stroke [111].

The PISCES 1 trial (Pilot Investigation of Stem Cells in Stroke; ClinicalTrials.gov, number NCT01151124) was a first-in-human study using neuronal progenitor cells (NPCs) derived from the human fetal cortex to treat patients in the chronic phase after damage to the basal ganglia. This trial was an open-label, single-site, dose-escalation study [112]. The cells were modified with the c-Myc gene to enable chemical control of proliferation (CTX cells). CTX cells produce multiple growth factors and cytokines that promote angiogenesis and neurogenesis, and reduce inflammation $[112,113]$. In this study, 11 patients were enrolled from 6-60 months after stroke onset. CTX cells were transplanted stereotactically through a single injection into the ipsilateral putamen. During this trial, no immunological or cell-related adverse events were reported. The patients who received the CTX cells experienced improvements in their NIHSS and Ashworth Spasticity Scale scores, and neurological improvements were seen within one month from the procedure, which were maintained at the two-year follow-up. Moreover, three patients who were followed up for over two years experienced improvement of their $\mathrm{mRS}$ scores by 1 point. In addition, hyperintensity around the implantation tracts was seen in five patients based on fluid-attenuated inversion recovery MRI, but this did not correlate with clinical improvements. The study showed the safety of CTX cell transplantation, which could improve neurological function in patients in the chronic phase post-stroke [112].

The PISCES 2 study (ClinicalTrials.gov, number NCT02117635) was a prospective, multicenter, single-arm, open-label study in adults over 40 years of age who experienced significant upper limb motor deficits 2-13 months (median: 7 months) after ischemic stroke [114]. Twenty-three patients received transplantations of 20 million CTX cells into the ipsilateral putamen. No safety concerns related to the cells were reported at one year. One patient demonstrated improved Action Research Arm Test performance at 3 months, and three patients improved after 6-12 months. Seven patients had improved mRS scores by at least 1 point. In total, 15 patients showed improvement on one or more of the clinical scales [114].

Subsequently, the PISCES-3 study (ClinicalTrials.gov, number NCT03629275) was a randomized, placebo-controlled, Phase IIb clinical trial [113]. This trial enrolled about 130 patients 6-24 months 
after a stroke from 40 centers across the United States who had moderate to moderately severe functional disability (with a baseline mRS score of 3-4). The patients were randomized using a 1:1 ratio (CTX implantation: sham surgery control), and received stereotactic implantations of 20 million CTX cells into the putamen ipsilateral to the cerebral infarct. The sham surgery group received a partial thickness burr-hole without insertion of the cannula or penetration of the dura. The primary outcome was an improvement of mRS scores six months after the procedure, with further monitoring up to 12 months.

\section{Induced Pluripotent Stem Cells}

Mice-induced pluripotent stem (iPS) cells were first established by Yamanaka et al. with introducing four transcription factors (Oct3/4, Klf4, Sox2, and c-myc) into mouse fibroblasts [115]. iPSCs can be an ideal source of cells for cell therapy, as they can be reprogrammed from somatic or blood cells, theoretically from any individual, and have limitless self-renewal capacity and pluripotency, allowing them to differentiate into all cell types derived from the three germ layers (endoderm, mesoderm, and ectoderm) $[115,116]$. These advantages are not common to other stem cells such as MSCs or NSCs, and the research and application of iPSC products provoke less ethical controversy than embryonic stem cells. Nonetheless, there are still several hurdles to overcome.

\subsection{Applying Induced Pluripotent Stem Cells in Animal Models of Stroke}

To date, the application of iPSCs in cell therapy for stroke has been solely tested in animal stroke models. The earliest studies assessed the effects of transplanting undifferentiated iPSCs into the ischemic brain or the subdural space adjacent to the site of infarction in rat or mouse MCAO models [117-120]. The results were not consistent in terms of treatment effects, as some observed improvements $[117,118]$ while others did not [119]. Not surprisingly, transplanted iPSCs were associated with tumorigenicity $[119,120]$, which was more evident when the cells were transplanted into ischemic lesions of pathological brain tissue than into healthy brains [120].

Thereafter, differentiated iPSCs or iPSC derivatives were used in animal models [121-127]. In almost all experimental studies, iPSCs were differentiated into cells that shared characteristics common to immature neuronal cells; these became known as NSCs or NPCs. These NSCs and NPCs were transplanted into ischemic brains, resulting in beneficial treatment effects, such as reduced infarct volume or symptom improvement, and no tumor formation was reported when differentiated iPSCs were used. Transplanted cells could survive for a certain period of time, allowing them to migrate toward the peri-infarct zone and further differentiate into neurons or astrocytes. Most studies concluded that transplanted cells contributed to improvements mainly via secreting trophic factors or immunomodulators to reduce inflammation, support residual tissue and enhance regeneration, or by forming connections with host neural networks, resulting in reduced brain atrophy, rather than neuronal replacement. However, Tornero et al. reported that transplanted iPSC-derived neuroepithelial-like stem cells differentiated into neurons with a cortical phenotype and developed functional synapses with host neurons, showing replacement was possible [128,129].

Recent studies have focused on expanding applications of iPSCs in animal models of aging [130], and tried to determine the optimal timing for transplantation in terms of differentiation states $[131,132]$ and the effect of pathological conditions on transplanted cell viability and differentiation [133]. These studies showed that iPSC-derived cells were also effective in reducing the damage caused by aging or reactive gliosis, and completely differentiated cells could result in decreased viability after transplantation. Moreover, iPSC-derived NPCs were tested in models with larger animals, such as the porcine stroke model, revealing a reduction in inflammation and amelioration of stroke-associated symptoms $[134,135]$. 


\subsection{Merits and Hurdles of Using Induced Pluripotent Stem Cells for Cell Therapy to Treat Stroke}

Some reviews have summarized the applications of iPSCs in cell therapies [136]. Most previous attempts aimed to use iPSCs after differentiation into specific cell types, mainly NSCs. Therefore, theoretically, the unique mechanisms through which iPSCs protect against damage compared to other stem cells are unknown. Inherent properties of iPSCs, such as limitless potential for self-renewal and pluripotency could be a huge advantage. For example, iPSCs may be associated with a lower rejection rate following transplantation [137], and genetically engineered iPSCs can be enriched to enhance secretion of specific hormones. In addition, various stages of differentiated cells derived from the same iPSC line could be used to target phase post-stroke; immature iPSC-derived NSCs can suppress inflammation in the acute phase and mature neuroepithelial-like cells could be used as cell replacement in the chronic phase. The therapeutic time window may not be long in the acute phase, so being able to tailor treatment for stroke patients would be beneficial. However, some inherent properties of iPSCs may need to be overcome. Limitless self-renewal is associated with tumorigenesis, and the pluripotency of these cells means there is a need to identify the optimal cell type or differentiation state. Detecting and excluding undifferentiated iPSCs, evaluating the tumorigenicity of the differentiated cells, and developing differentiation methods with xeno-free, chemically defined media is critical. While iPSCs are a promising source for cell therapy, there are many hurdles to be overcome.

\section{Gene Modifications in Stem Cell Therapy to Repair Stroke-Induced Damage}

Stem cell-based gene therapy is a promising and effective therapeutic strategy for stroke. Stem cells act as gene delivery vehicles while also secreting various neurotrophic factors. Transplantation of gene-modified stem cells overexpressing various growth factors or cytokines, such as BDNF, GDNF, NGF, VEGF, hepatocyte growth factor (HGF), placental growth factor (PIGF), angiopoietin-1 (ANG-1), erythropoietin (EPO), IL-10, and Noggin has been demonstrated to significantly promote functional recovery compared to stem cells alone in experimental stroke models.

\subsection{Brain-Derived Neurotrophic Factor}

BDNF gene-transfected MSCs using an adeno-associated virus (AAV) vector can significantly reduce infarct volumes and improve motor function compared with MSC monotherapy in the rat transient MCAO model [138]. BDNF promotes the survival and differentiation of neuronal tissue by upregulating B-cell lymphoma 2 (Bcl-2) and downregulating Bcl-2 associated X protein (Bax) within the ischemic penumbra [139]. Moreover, BDNF can promote the activation of astrocytes [140], and astrocyte-derived exosomes promote axonal elongation and functional recovery after the subacute phase of stroke [141].

\subsection{Glial-Derived Neurotrophic Factor}

GDNF gene-transfected MSCs using an AAV vector have been shown to significantly reduce infarct volumes and improve motor function in the rat transient MCAO model [138]. GDNF has an important role in neuronal survival through binding to the GFR $\alpha 1$ (GDNF family receptor alpha-1) receptor and activating the receptor tyrosine kinase Ret [142].

\subsection{Nerve Growth Factor}

NGF gene-transfected MSCs using an AAV vector have been shown to promote neural cell survival and improve neurological deficits caused by ischemic stroke in the rat transient MCAO model [143]. NGF produced by MSCs is involved in early neurogenesis and the generation of certain neuropeptides [144]. 


\subsection{Vascular Endothelial Growth Factor}

Neural stem cells (NSCs) forced to overexpress VEGF using lipofection resulted in functional recovery in the mouse intracerebral hemorrhage (ICH) model [145]. Overexpressing VEGF provided differentiation and survival of grafted human NSCs and renewed angiogenesis in the host brain [145].

\subsection{Hepatocyte Growth Factor}

HGF gene-transfected MSCs using a herpes simplex virus type-1 vector significantly reduced infarct volumes and improved motor function in the rat transient MCAO model [146]. DPSCs overexpressing HGF using an AAV vector also enhanced therapeutic effects of DPSCs in the rat transient MCAO model [63]. HGF attenuates BBB destruction by protecting tight junction proteins such as Zo-1 and occludin [63].

\subsection{Placenta Growth Factor}

PIGF gene-transfected MSCs using an AAV vector significantly reduced infarct volumes and improved motor function in the rat permanent MCAO model [147]. PIGF contributes to angiogenesis after cerebral ischemia as a member of the VEGF family [147].

\subsection{Angiopoietin-1}

ANG-1 gene-transfected MSCs using an AAV vector resulted in structural-functional recovery through improved vascular formation and maturation in the rat permanent MCAO model [148] by contributing to post-stroke angiogenesis and maintaining BBB integrity [149].

\subsection{Erythropoietin}

EPO gene-transfected MSCs using a lentivirus vector promoted neural cell survival and improved neurological deficits caused by ischemic stroke in the rat transient MCAO model [150]. EPO is associated with neurotrophic, anti-oxidant, anti-apoptotic, and anti-inflammatory effects in focal brain ischemia [151].

\subsection{Interleukin-10}

MSCs overexpressing IL-10 using an AAV vector significantly reduced infarct volumes and improved motor function in the rat transient MCAO model [43]. IL-10 plays a neuroprotective and vasculoprotective role in cerebrovascular disorders by attenuating pro-inflammatory signals and upregulating anti-apoptotic proteins, such as Bcl-2 and Bcl-extra-large (Bcl-xL) [152,153]. Moreover, overexpression of IL-10 suppressed neuronal degeneration and improved survival of engrafted MSCs in the ischemic hemisphere [43].

\subsection{Noggin}

Noggin gene-transfected MSCs using an AAV vector significantly improved neurological function in the rat transient MCAO model [154]. Noggin, an antagonist of bone morphogenetic protein (BMP), promotes the differentiation of MSCs into neurons [154]. Moreover, noggin suppressed ischemia-induced apoptosis and inflammation through the protein kinase $\mathrm{B} / \mathrm{glycogen}$ synthase kinase 3 beta (Akt/GSK3 $\beta$ ) and toll-like receptor 4/myeloid differentiation primary response 88 (TLR4/MyD88) pathways in the rat MCAO model [143]. In addition, the co-transfection of Noggin and NGF or BDNF in MSCs induces synergistic effects resulting in improved neurological outcomes and neural remodeling compared to singly transfected (NGF or BDNF) BMSCs $[143,154]$.

\section{Perspectives}

Stem cells have become attractive candidates for cell therapy in stroke treatment, though so far, no ideal therapeutic interventions are available. Although stem cells are associated with 
various beneficial effects, including neuroprotection, reduced inflammatory and immune responses, and increased angiogenesis and neurogenesis, the main mechanism through which each cell type is able to attenuate the damage caused by a stroke is yet to be clarified. Clinical challenges may include complicating factors, such as the effect of age, co-morbidities, stroke subtype, and stroke severity, all of which can affect the efficacy of cell therapy. It will take coordinated basic science and clinical collaborations before cell therapy can become a standard stroke treatment. In the future, a combination of stem cell and gene therapy will play an important role in experimental models and clinical treatments.

Funding: This research was funded by JSPS Kakenhi Grants (Number 19K09492 to Satoshi Suda).

Conflicts of Interest: Satoshi Suda received research funding from the All Japan Coffee Association, and lecture fees from Eisai Co., Ltd. Chikako Nito received research funding from the Kaneka Co., Ltd. Kazumi Kimura received lecture fees from Bristol-Myers Squibb Co., Ltd., Nippon Boehringer Ingelheim Co., Ltd., Bayer Healthcare Co., Ltd. and Daiichi Sankyo Co., Ltd., and research funding from Nippon Boehringer Ingelheim Co., Ltd., Daiichi Sankyo Co., Ltd., and Teijin Pharma Co., Ltd.

\section{Abbreviations}

$\begin{array}{ll}\text { MNCs } & \text { Mononuclear cells } \\ \text { BMSCs } & \text { Bone marrow mesenchymal stem cells } \\ \text { DPSCs } & \text { Dental pulp stem cells } \\ \text { NSCs } & \text { Neural stem cells } \\ \text { iPSCs } & \text { Inducible pluripotent stem cells } \\ \text { VEGF } & \text { Vascular endothelial growth factor } \\ \text { HGF } & \text { Hepatocyte growth factor } \\ \text { BDNF } & \text { Brain-derived neurotrophic factor } \\ \text { GDNF } & \text { Glial-derived neurotrophic factor } \\ \text { Il-1 } \beta & \text { Interleukin 1 beta } \\ \text { Il-6 } & \text { Interleukin 6 } \\ \text { Il-2 } & \text { Interleukin 2 } \\ \text { IFN- } \gamma & \text { Interferon gamma } \\ \text { TNF- } \alpha & \text { Tumor necrosis factor alpha } \\ \text { ECs } & \text { Endothelial cells } \\ \text { SMCs } & \text { Smooth muscle cells } \\ \text { MCAO } & \text { Middle cerebral artery occlusion } \\ \text { CBF } & \text { Cerebral blood flow } \\ \text { NIHSS } & \text { National Institutes of Health Stroke Scale } \\ \text { HLA-DR } & \text { Human leukocyte antigen DR isotype } \\ \text { Treg } & \text { Regulatory T cell } \\ \text { mRS } & \text { Modified Rankin Scale } \\ \text { ALDH } & \text { Aldehyde dehydrogenase } \\ \text { EQ-50 } & \text { European Quality of Life- } 5 \text { dimension } \\ \text { MSCs } & \text { Mesenchymal stem cells } \\ \text { CNS } & \text { Central nervous system } \\ \text { EGF } & \text { Epidermal growth factor } \\ \text { SVZ } & \text { Sub-ventricular zone } \\ \text { SGZ } & \text { Sub-granular zone } \\ \text { FGF } & \text { Fibroblast growth factor } \\ \text { ANG-1 } & \text { Angiopoietin 1 } \\ \text { EO } & \text { Erythropoietin } \\ \text { AAV } & \text { Adeno-associated virus } \\ \text { Bcl-2 } & \text { B cell lymphoma 2 } \\ \text { Bax } & \text { Bcl-2 associated X } \\ \text { ICH } & \text { Intracerebral hemorrhage } \\ \text { BCP } & \text { Bone morphogenetic protein } \\ & \end{array}$




\section{References}

1. Bang, O.Y.; Lee, J.S.; Lee, P.H.; Lee, G. Autologous mesenchymal stem cell transplantation in stroke patients. Ann. Neurol. 2005, 57, 874-882. [CrossRef]

2. Bhatia, V.; Gupta, V.; Khurana, D.; Sharma, R.R.; Khandelwal, N. Randomized Assessment of the Safety and Efficacy of Intra-Arterial Infusion of Autologous Stem Cells in Subacute Ischemic Stroke. AJNR Am. J. Neuroradiol. 2018, 39, 899-904. [CrossRef] [PubMed]

3. Hess, D.C.; Wechsler, L.R.; Clark, W.M.; Savitz, S.I.; Ford, G.A.; Chiu, D.; Yavagal, D.R.; Uchino, K.; Liebeskind, D.S.; Auchus, A.P.; et al. Safety and efficacy of multipotent adult progenitor cells in acute ischaemic stroke (MASTERS): A randomised, double-blind, placebo-controlled, phase 2 trial. Lancet Neurol. 2017, 16, 360-368. [CrossRef]

4. Honmou, O.; Houkin, K.; Matsunaga, T.; Niitsu, Y.; Ishiai, S.; Onodera, R.; Waxman, S.G.; Kocsis, J.D. Intravenous administration of auto serum-expanded autologous mesenchymal stem cells in stroke. Brain 2011, 134, 1790-1807. [CrossRef] [PubMed]

5. Levy, M.L.; Crawford, J.R.; Dib, N.; Verkh, L.; Tankovich, N.; Cramer, S.C. Phase I/II Study of Safety and Preliminary Efficacy of Intravenous Allogeneic Mesenchymal Stem Cells in Chronic Stroke. Stroke 2019, 50, 2835-2841. [CrossRef] [PubMed]

6. Savitz, S.I.; Yavagal, D.; Rappard, G.; Likosky, W.; Rutledge, N.; Graffagnino, C.; Alderazi, Y.; Elder, J.A.; Chen, P.R.; Budzik, R.F., Jr.; et al. A Phase 2 Randomized, Sham-Controlled Trial of Internal Carotid Artery Infusion of Autologous Bone Marrow-Derived ALD-401 Cells in Patients With Recent Stable Ischemic Stroke (RECOVER-Stroke). Circulation 2019, 139, 192-205. [CrossRef]

7. Shichinohe, H.; Kawabori, M.; Iijima, H.; Teramoto, T.; Abumiya, T.; Nakayama, N.; Kazumata, K.; Terasaka, S.; Arato, T.; Houkin, K. Research on advanced intervention using novel bone marrOW stem cell (RAINBOW): A study protocol for a phase I, open-label, uncontrolled, dose-response trial of autologous bone marrow stromal cell transplantation in patients with acute ischemic stroke. BMC Neurol. 2017, 17, 179. [CrossRef]

8. Steinberg, G.K.; Kondziolka, D.; Wechsler, L.R.; Lunsford, L.D.; Coburn, M.L.; Billigen, J.B.; Kim, A.S.; Johnson, J.N.; Bates, D.; King, B.; et al. Clinical Outcomes of Transplanted Modified Bone Marrow-Derived Mesenchymal Stem Cells in Stroke: A Phase 1/2a Study. Stroke 2016, 47, 1817-1824. [CrossRef]

9. Savitz, S.I.; Parsha, K. Enhancing Stroke Recovery with Cellular Therapies. In Stroke, 6th ed.; Grotta, J.C., Albers, G.W., Broderick, J.P., Kasner, S.E., Lo, E.H., Mendelow, A.D., Sacco, R.L., Wong, L.K.S., Eds.; Elsevier: London, UK, 2016; pp. 981-991.

10. Suda, S.; Yang, B.; Schaar, K.; Xi, X.; Pido, J.; Parsha, K.; Aronowski, J.; Savitz, S.I. Autologous Bone Marrow Mononuclear Cells Exert Broad Effects on Short- and Long-Term Biological and Functional Outcomes in Rodents with Intracerebral Hemorrhage. Stem Cells Dev. 2015, 24, 2756-2766. [CrossRef]

11. Kamiya, F.; Ueda, M.; Nito, C.; Kamiya, N.; Inaba, T.; Suda, S.; Saito, T.; Muraga, K.; Katayama, Y. Effect of repeated allogeneic bone marrow mononuclear cell transplantation on brain injury following transient focal cerebral ischemia in rats. Life Sci. 2014, 95, 22-28. [CrossRef]

12. Kamiya, N.; Ueda, M.; Igarashi, H.; Nishiyama, Y.; Suda, S.; Inaba, T.; Katayama, Y. Intra-arterial transplantation of bone marrow mononuclear cells immediately after reperfusion decreases brain injury after focal ischemia in rats. Life Sci. 2008, 83, 433-437. [CrossRef] [PubMed]

13. Higashi, Y.; Kimura, M.; Hara, K.; Noma, K.; Jitsuiki, D.; Nakagawa, K.; Oshima, T.; Chayama, K.; Sueda, T.; Goto, C.; et al. Autologous bone-marrow mononuclear cell implantation improves endothelium-dependent vasodilation in patients with limb ischemia. Circulation 2004, 109, 1215-1218. [CrossRef]

14. Penicka, M.; Lang, O.; Widimsky, P.; Kobylka, P.; Kozak, T.; Vanek, T.; Dvorak, J.; Tintera, J.; Bartunek, J. One-day kinetics of myocardial engraftment after intracoronary injection of bone marrow mononuclear cells in patients with acute and chronic myocardial infarction. Heart 2007, 93, 837-841. [CrossRef] [PubMed]

15. Burchfield, J.S.; Iwasaki, M.; Koyanagi, M.; Urbich, C.; Rosenthal, N.; Zeiher, A.M.; Dimmeler, S. Interleukin-10 from transplanted bone marrow mononuclear cells contributes to cardiac protection after myocardial infarction. Circ. Res. 2008, 103, 203-211. [CrossRef] [PubMed]

16. Pokushalov, E.; Romanov, A.; Chernyavsky, A.; Larionov, P.; Terekhov, I.; Artyomenko, S.; Poveshenko, O.; Kliver, E.; Shirokova, N.; Karaskov, A.; et al. Efficiency of intramyocardial injections of autologous bone marrow mononuclear cells in patients with ischemic heart failure: A randomized study. J. Cardiovasc. Transl. Res. 2010, 3, 160-168. [CrossRef] 
17. Troidl, K.; Schaper, W. Arteriogenesis versus angiogenesis in peripheral artery disease. Diabetes/Metab. Res. Rev. 2012, 28 (Suppl. 1), 27-29. [CrossRef]

18. Raval, Z.; Losordo, D.W. Cell therapy of peripheral arterial disease: From experimental findings to clinical trials. Circ. Res. 2013, 112, 1288-1302. [CrossRef]

19. Terry, T.; Chen, Z.; Dixon, R.A.; Vanderslice, P.; Zoldhelyi, P.; Willerson, J.T.; Liu, Q. CD34(+)/M-cadherin(+) bone marrow progenitor cells promote arteriogenesis in ischemic hindlimbs of ApoE(-)/(-) mice. PLoS ONE 2011, 6, e20673. [CrossRef]

20. Wang, J.; Yu, L.; Jiang, C.; Chen, M.; Ou, C.; Wang, J. Bone marrow mononuclear cells exert long-term neuroprotection in a rat model of ischemic stroke by promoting arteriogenesis and angiogenesis. Brain Behav. Immun. 2013, 34, 56-66. [CrossRef]

21. Wang, J.; Fu, X.; Jiang, C.; Yu, L.; Wang, M.; Han, W.; Liu, L.; Wang, J. Bone marrow mononuclear cell transplantation promotes therapeutic angiogenesis via upregulation of the VEGF-VEGFR2 signaling pathway in a rat model of vascular dementia. Behav. Brain Res. 2014, 265, 171-180. [CrossRef]

22. Fujita, Y.; Ihara, M.; Ushiki, T.; Hirai, H.; Kizaka-Kondoh, S.; Hiraoka, M.; Ito, H.; Takahashi, R. Early protective effect of bone marrow mononuclear cells against ischemic white matter damage through augmentation of cerebral blood flow. Stroke 2010, 41, 2938-2943. [CrossRef] [PubMed]

23. Wang, J.; Liu, X.; Lu, H.; Jiang, C.; Cui, X.; Yu, L.; Fu, X.; Li, Q.; Wang, J. CXCR4(+)CD45(-) BMMNC subpopulation is superior to unfractionated BMMNCs for protection after ischemic stroke in mice. Brain Behav. Immun. 2015, 45, 98-108. [CrossRef] [PubMed]

24. Chen, J.; Zhang, Z.G.; Li, Y.; Wang, L.; Xu, Y.X.; Gautam, S.C.; Lu, M.; Zhu, Z.; Chopp, M. Intravenous administration of human bone marrow stromal cells induces angiogenesis in the ischemic boundary zone after stroke in rats. Circ. Res. 2003, 92, 692-699. [CrossRef] [PubMed]

25. Kikuchi-Taura, A.; Okinaka, Y.; Takeuchi, Y.; Ogawa, Y.; Maeda, M.; Kataoka, Y.; Yasui, T.; Kimura, T.; Gul, S.; Claussen, C.; et al. Bone Marrow Mononuclear Cells Activate Angiogenesis via Gap Junction-Mediated Cell-Cell Interaction. Stroke 2020, 51, 1279-1289. [CrossRef] [PubMed]

26. Okinaka, Y.; Kikuchi-Taura, A.; Takeuchi, Y.; Ogawa, Y.; Boltze, J.; Gul, S.; Claussen, C.; Taguchi, A. Clot-Derived Contaminants in Transplanted Bone Marrow Mononuclear Cells Impair the Therapeutic Effect in Stroke. Stroke 2019, 50, 2883-2891. [CrossRef] [PubMed]

27. Yang, B.; Li, W.; Satani, N.; Nghiem, D.M.; Xi, X.; Aronowski, J.; Savitz, S.I. Protective Effects of Autologous Bone Marrow Mononuclear Cells After Administering t-PA in an Embolic Stroke Model. Transl. Stroke Res. 2018, 9, 135-145. [CrossRef] [PubMed]

28. Li, Y.; Mao, W.W.; Zhang, C.G.; Wan, L.; Jing, C.H.; Hua, X.M.; Li, S.T.; Cheng, J. Neuroprotective effects of intravenous transplantation of bone marrow mononuclear cells from 5-fluorouracil pre-treated rats on ischemic stroke. Behav. Brain Res. 2016, 301, 287-292. [CrossRef]

29. Yang, B.; Migliati, E.; Parsha, K.; Schaar, K.; Xi, X.; Aronowski, J.; Savitz, S.I. Intra-arterial delivery is not superior to intravenous delivery of autologous bone marrow mononuclear cells in acute ischemic stroke. Stroke 2013, 44, 3463-3472. [CrossRef]

30. Nakano-Doi, A.; Nakagomi, T.; Fujikawa, M.; Nakagomi, N.; Kubo, S.; Lu, S.; Yoshikawa, H.; Soma, T.; Taguchi, A.; Matsuyama, T. Bone marrow mononuclear cells promote proliferation of endogenous neural stem cells through vascular niches after cerebral infarction. Stem Cells 2010, 28, 1292-1302. [CrossRef]

31. Savitz, S.I.; Misra, V.; Kasam, M.; Juneja, H.; Cox, C.S., Jr.; Alderman, S.; Aisiku, I.; Kar, S.; Gee, A.; Grotta, J.C. Intravenous autologous bone marrow mononuclear cells for ischemic stroke. Ann. Neurol. 2011, 70, 59-69. [CrossRef]

32. Taguchi, A.; Sakai, C.; Soma, T.; Kasahara, Y.; Stern, D.M.; Kajimoto, K.; Ihara, M.; Daimon, T.; Yamahara, K.; Doi, K.; et al. Intravenous Autologous Bone Marrow Mononuclear Cell Transplantation for Stroke: Phase1/2a Clinical Trial in a Homogeneous Group of Stroke Patients. Stem Cells Dev. 2015, 24, 2207-2218. [CrossRef] [PubMed]

33. Prasad, K.; Sharma, A.; Garg, A.; Mohanty, S.; Bhatnagar, S.; Johri, S.; Singh, K.K.; Nair, V.; Sarkar, R.S.; Gorthi, S.P.; et al. Intravenous autologous bone marrow mononuclear stem cell therapy for ischemic stroke: A multicentric, randomized trial. Stroke 2014, 45, 3618-3624. [CrossRef] [PubMed]

34. Boltze, J.; Modo, M.M.; Mays, R.W.; Taguchi, A.; Jolkkonen, J.; Savitz, S.I. Stem Cells as an Emerging Paradigm in Stroke 4: Advancing and Accelerating Preclinical Research. Stroke 2019, 50, 3299-3306. [CrossRef] [PubMed] 
35. Javazon, E.H.; Beggs, K.J.; Flake, A.W. Mesenchymal stem cells: Paradoxes of passaging. Exp. Hematol. 2004, 32, 414-425. [CrossRef] [PubMed]

36. Gnecchi, M.; Melo, L.G. Bone marrow-derived mesenchymal stem cells: Isolation, expansion, characterization, viral transduction, and production of conditioned medium. Methods Mol. Biol. 2009, 482, 281-294. [PubMed]

37. Kuroda, S.; Houkin, K. Translational challenge for bone marrow stroma cell therapy after stroke. Front. Neurol. Neurosci. 2013, 32, 62-68. [PubMed]

38. Suda, S.; Shimazaki, K.; Ueda, M.; Inaba, T.; Kamiya, N.; Katsura, K.; Katayama, Y. Combination therapy with bone marrow stromal cells and FK506 enhanced amelioration of ischemic brain damage in rats. Life Sci. 2011, 89, 50-56. [CrossRef]

39. Dulamea, A.O. The potential use of mesenchymal stem cells in stroke therapy-From bench to bedside. J. Neurol. Sci. 2015, 352, 1-11. [CrossRef]

40. Li, G.; Yu, F.; Lei, T.; Gao, H.; Li, P.; Sun, Y.; Huang, H.; Mu, Q. Bone marrow mesenchymal stem cell therapy in ischemic stroke: Mechanisms of action and treatment optimization strategies. Neural. Regen. Res. 2016, 11, 1015-1024. [CrossRef]

41. Wang, Z.; He, D.; Zeng, Y.Y.; Zhu, L.; Yang, C.; Lu, Y.J.; Huang, J.Q.; Cheng, X.Y.; Huang, X.H.; Tan, X.J. The spleen may be an important target of stem cell therapy for stroke. J. Neuroinflamm. 2019, 16, 20. [CrossRef]

42. Tobin, M.K.; Stephen, T.K.L.; Lopez, K.L.; Pergande, M.R.; Bartholomew, A.M.; Cologna, S.M.; Lazarov, O. Activated Mesenchymal Stem Cells Induce Recovery Following Stroke Via Regulation of Inflammation and Oligodendrogenesis. J. Am. Heart Assoc. 2020, 9, e013583. [CrossRef]

43. Nakajima, M.; Nito, C.; Sowa, K.; Suda, S.; Nishiyama, Y.; Nakamura-Takahashi, A.; Nitahara-Kasahara, Y.; Imagawa, K.; Hirato, T.; Ueda, M.; et al. Mesenchymal Stem Cells Overexpressing Interleukin-10 Promote Neuroprotection in Experimental Acute Ischemic Stroke. Mol. Ther. Methods Clin. Dev. 2017, 6, 102-111. [CrossRef] [PubMed]

44. Kawabori, M.; Kuroda, S.; Ito, M.; Shichinohe, H.; Houkin, K.; Kuge, Y.; Tamaki, N. Timing and cell dose determine therapeutic effects of bone marrow stromal cell transplantation in rat model of cerebral infarct. Neuropathology 2013, 33, 140-148. [CrossRef]

45. Toyoshima, A.; Yasuhara, T.; Kameda, M.; Morimoto, J.; Takeuchi, H.; Wang, F.; Sasaki, T.; Sasada, S.; Shinko, A.; Wakamori, T.; et al. Intra-Arterial Transplantation of Allogeneic Mesenchymal Stem Cells Mounts Neuroprotective Effects in a Transient Ischemic Stroke Model in Rats: Analyses of Therapeutic Time Window and Its Mechanisms. PLoS ONE 2015, 10, e0127302. [CrossRef] [PubMed]

46. Nakazaki, M.; Sasaki, M.; Kataoka-Sasaki, Y.; Oka, S.; Suzuki, J.; Sasaki, Y.; Nagahama, H.; Hashi, K.; Kocsis, J.D.; Honmou, O. Intravenous infusion of mesenchymal stem cells improves impaired cognitive function in a cerebral small vessel disease model. Neuroscience 2019, 408, 361-377. [CrossRef] [PubMed]

47. Wang, L.Q.; Lin, Z.Z.; Zhang, H.X.; Shao, B.; Xiao, L.; Jiang, H.G.; Zhuge, Q.C.; Xie, L.K.; Wang, B.; $\mathrm{Su}, \mathrm{D} . \mathrm{M}$; et al. Timing and dose regimens of marrow mesenchymal stem cell transplantation affect the outcomes and neuroinflammatory response after ischemic stroke. CNS Neurosci. Ther. 2014, 20, 317-326. [CrossRef]

48. Steinberg, G.K.; Kondziolka, D.; Wechsler, L.R.; Lunsford, L.D.; Kim, A.S.; Johnson, J.N.; Bates, D.; Poggio, G.; Case, C.; McGrogan, M.; et al. Two-year safety and clinical outcomes in chronic ischemic stroke patients after implantation of modified bone marrow-derived mesenchymal stem cells (SB623): A phase 1/2a study. J. Neurosurg. 2018, 131, 1462-1472. [CrossRef]

49. Kawabori, M.; Tanimori, A.; Kitta, S.; Shichinohe, H.; Houkin, K. Evaluation of Novel Stereotactic Cannula for Stem Cell Transplantation against Central Nervous System Disease. Stem Cells Int. 2020, 2020, 4085617. [CrossRef]

50. Nosrat, I.V.; Smith, C.A.; Mullally, P.; Olson, L.; Nosrat, C.A. Dental pulp cells provide neurotrophic support for dopaminergic neurons and differentiate into neurons in vitro; implications for tissue engineering and repair in the nervous system. Eur. J. Neurosci. 2004, 19, 2388-2398. [CrossRef]

51. Pierdomenico, L.; Bonsi, L.; Calvitti, M.; Rondelli, D.; Arpinati, M.; Chirumbolo, G.; Becchetti, E.; Marchionni, C.; Alviano, F.; Fossati, V.; et al. Multipotent mesenchymal stem cells with immunosuppressive activity can be easily isolated from dental pulp. Transplantation 2005, 80, 836-842. [CrossRef]

52. Gronthos, S.; Mankani, M.; Brahim, J.; Robey, P.G.; Shi, S. Postnatal human dental pulp stem cells (DPSCs) in vitro and in vivo. Proc. Natl. Acad. Sci. USA 2000, 97, 13625-13630. [CrossRef] [PubMed] 
53. Ponnaiyan, D.; Jegadeesan, V. Comparison of phenotype and differentiation marker gene expression profiles in human dental pulp and bone marrow mesenchymal stem cells. Eur. J. Dent. 2014, 8, 307-313. [CrossRef] [PubMed]

54. Rajendran, R.; Gopal, S.; Masood, H.; Vivek, P.; Deb, K. Regenerative potential of dental pulp mesenchymal stem cells harvested from high caries patient's teeth. J. Stem Cells 2013, 8, 25-41. [PubMed]

55. Zhang, X.; Zhou, Y.; Li, H.; Wang, R.; Yang, D.; Li, B.; Fu, J. Intravenous administration of DPSCs and BDNF improves neurological performance in rats with focal cerebral ischemia. Int. J. Mol. Med. 2018, 41, 3185-3194. [CrossRef] [PubMed]

56. Inoue, T.; Sugiyama, M.; Hattori, H.; Wakita, H.; Wakabayashi, T.; Ueda, M. Stem cells from human exfoliated deciduous tooth-derived conditioned medium enhance recovery of focal cerebral ischemia in rats. Tissue Eng. Part A 2013, 19, 24-29. [CrossRef] [PubMed]

57. Leong, W.K.; Lewis, M.D.; Koblar, S.A. Concise review: Preclinical studies on human cell-based therapy in rodent ischemic stroke models: Where are we now after a decade? Stem Cells 2013, 31, 1040-1043. [CrossRef] [PubMed]

58. Sakai, K.; Yamamoto, A.; Matsubara, K.; Nakamura, S.; Naruse, M.; Yamagata, M.; Sakamoto, K.; Tauchi, R.; Wakao, N.; Imagama, S.; et al. Human dental pulp-derived stem cells promote locomotor recovery after complete transection of the rat spinal cord by multiple neuro-regenerative mechanisms. J. Clin. Investig. 2012, 122, 80-90. [CrossRef]

59. Kumasaka, A.; Kanazawa, K.; Ohke, H.; Miura, I.; Miura, Y. Post-ischemic Intravenous Administration of Allogeneic Dental Pulp-Derived Neurosphere Cells Ameliorated Outcomes of Severe Forebrain Ischemia in Rats. Neurocritical Care 2017, 26, 133-142. [CrossRef]

60. Leong, W.K.; Henshall, T.L.; Arthur, A.; Kremer, K.L.; Lewis, M.D.; Helps, S.C.; Field, J.; Hamilton-Bruce, M.A.; Warming, S.; Manavis, J.; et al. Human adult dental pulp stem cells enhance poststroke functional recovery through non-neural replacement mechanisms. Stem Cells Transl. Med. 2012, 1, 177-187. [CrossRef]

61. Song, M.; Lee, J.H.; Bae, J.; Bu, Y.; Kim, E.C. Human Dental Pulp Stem Cells Are More Effective than Human Bone Marrow-Derived Mesenchymal Stem Cells in Cerebral Ischemic Injury. Cell Transplant. 2017, 26, 1001-1016. [CrossRef]

62. Nito, C.; Sowa, K.; Nakajima, M.; Sakamoto, Y.; Suda, S.; Nishiyama, Y.; Nakamura-Takahashi, A.; Nitahara-Kasahara, Y.; Ueda, M.; Okada, T.; et al. Transplantation of human dental pulp stem cells ameliorates brain damage following acute cerebral ischemia. Biomed. Pharm. 2018, 108, 1005-1014. [CrossRef] [PubMed]

63. Sowa, K.; Nito, C.; Nakajima, M.; Suda, S.; Nishiyama, Y.; Sakamoto, Y.; Nitahara-Kasahara, Y.; Nakamura-Takahashi, A.; Ueda, M.; Kimura, K.; et al. Impact of Dental Pulp Stem Cells Overexpressing Hepatocyte Growth Factor after Cerebral Ischemia/Reperfusion in Rats. Mol. Ther. Methods Clin. Dev. 2018, 10, 281-290. [CrossRef]

64. Zhang, X.; Zhou, Y.; Li, H.; Wang, R.; Yang, D.; Li, B.; Cao, X.; Fu, J. Transplanted Dental Pulp Stem Cells Migrate to Injured Area and Express Neural Markers in a Rat Model of Cerebral Ischemia. Cell Physiol. Biochem. 2018, 45, 258-266. [CrossRef]

65. Savitz, S.I. Developing Cellular Therapies for Stroke. Stroke 2015, 46, 2026-2031. [CrossRef]

66. Kalladka, D.; Muir, K.W. Stem cell therapy in stroke: Designing clinical trials. Neurochem. Int. 2011, 59, 367-370. [CrossRef]

67. Ribeiro, T.B.; Duarte, A.S.; Longhini, A.L.; Pradella, F.; Farias, A.S.; Luzo, A.C.; Oliveira, A.L.; Olalla Saad, S.T. Neuroprotection and immunomodulation by xenografted human mesenchymal stem cells following spinal cord ventral root avulsion. Sci. Rep. 2015, 5, 16167. [CrossRef] [PubMed]

68. Lee, J.A.; Kim, B.I.; Jo, C.H.; Choi, C.W.; Kim, E.K.; Kim, H.S.; Yoon, K.S.; Choi, J.H. Mesenchymal stem-cell transplantation for hypoxic-ischemic brain injury in neonatal rat model. Pediatr. Res. 2010, 67, 42-46. [CrossRef] [PubMed]

69. Martire, A.; Bedada, F.B.; Uchida, S.; Poling, J.; Kruger, M.; Warnecke, H.; Richter, M.; Kubin, T.; Herold, S.; Braun, T. Mesenchymal stem cells attenuate inflammatory processes in the heart and lung via inhibition of TNF signaling. Basic Res. Cardiol. 2016, 111, 54. [CrossRef] [PubMed]

70. Shichita, T.; Ago, T.; Kamouchi, M.; Kitazono, T.; Yoshimura, A.; Ooboshi, H. Novel therapeutic strategies targeting innate immune responses and early inflammation after stroke. J. Neurochem. 2012, 123 (Suppl. 2), 29-38. [CrossRef] 
71. Nosrat, I.V.; Widenfalk, J.; Olson, L.; Nosrat, C.A. Dental pulp cells produce neurotrophic factors, interact with trigeminal neurons in vitro, and rescue motoneurons after spinal cord injury. Dev. Biol. 2001, 238, 120-132. [CrossRef] [PubMed]

72. Matsushita, K.; Motani, R.; Sakuta, T.; Yamaguchi, N.; Koga, T.; Matsuo, K.; Nagaoka, S.; Abeyama, K.; Maruyama, I.; Torii, M. The role of vascular endothelial growth factor in human dental pulp cells: Induction of chemotaxis, proliferation, and differentiation and activation of the AP-1-dependent signaling pathway. J. Dent. Res. 2000, 79, 1596-1603. [CrossRef]

73. Liu, X.; Ye, R.; Yan, T.; Yu, S.P.; Wei, L.; Xu, G.; Fan, X.; Jiang, Y.; Stetler, R.A.; Liu, G.; et al. Cell based therapies for ischemic stroke: From basic science to bedside. Prog. Neurobiol. 2014, 115, 92-115. [CrossRef] [PubMed]

74. Liesz, A.; Bauer, A.; Hoheisel, J.D.; Veltkamp, R. Intracerebral interleukin-10 injection modulates post-ischemic neuroinflammation: An experimental microarray study. Neurosci. Lett. 2014, 579, 18-23. [CrossRef] [PubMed]

75. Zhang, Z.G.; Zhang, L.; Jiang, Q.; Zhang, R.; Davies, K.; Powers, C.; Bruggen, N.; Chopp, M. VEGF enhances angiogenesis and promotes blood-brain barrier leakage in the ischemic brain. J. Clin. Investig. 2000, 106, 829-838. [CrossRef] [PubMed]

76. Király, M.; Kádár, K.; Horváthy, D.B.; Nardai, P.; Rácz, G.Z.; Lacza, Z.; Varga, G.; Gerber, G. Integration of neuronally predifferentiated human dental pulp stem cells into rat brain in vivo. Neurochem. Int. 2011, 59, 371-381. [CrossRef] [PubMed]

77. Jin, K.; Sun, Y.; Xie, L.; Mao, X.O.; Childs, J.; Peel, A.; Logvinova, A.; Banwait, S.; Greenberg, D.A. Comparison of ischemia-directed migration of neural precursor cells after intrastriatal, intraventricular, or intravenous transplantation in the rat. Neurobiol. Dis. 2005, 18, 366-374. [CrossRef] [PubMed]

78. Walczak, P.; Zhang, J.; Gilad, A.A.; Kedziorek, D.A.; Ruiz-Cabello, J.; Young, R.G.; Pittenger, M.F.; van Zijl, P.C.; Huang, J.; Bulte, J.W. Dual-modality monitoring of targeted intraarterial delivery of mesenchymal stem cells after transient ischemia. Stroke 2008, 39, 1569-1574. [CrossRef]

79. Ge, J.; Guo, L.; Wang, S.; Zhang, Y.; Cai, T.; Zhao, R.C.; Wu, Y. The size of mesenchymal stem cells is a significant cause of vascular obstructions and stroke. Stem Cell Rev. 2014, 10, 295-303. [CrossRef]

80. Lee, J.S.; Hong, J.M.; Moon, G.J.; Lee, P.H.; Ahn, Y.H.; Bang, O.Y. A long-term follow-up study of intravenous autologous mesenchymal stem cell transplantation in patients with ischemic stroke. Stem Cells 2010, 28, 1099-1106. [CrossRef]

81. Altman, J. Are new neurons formed in the brains of adult mammals? Science 1962, 135, 1127-1128. [CrossRef]

82. Reynolds, B.A.; Tetzlaff, W.; Weiss, S. A multipotent EGF-responsive striatal embryonic progenitor cell produces neurons and astrocytes. J. Neurosci. 1992, 12, 4565-4574. [CrossRef]

83. Reynolds, B.A.; Weiss, S. Generation of neurons and astrocytes from isolated cells of the adult mammalian central nervous system. Science 1992, 255, 1707-1710. [CrossRef] [PubMed]

84. Gritti, A.; Bonfanti, L.; Doetsch, F.; Caille, I.; Alvarez-Buylla, A.; Lim, D.A.; Galli, R.; Verdugo, J.M.; Herrera, D.G.; Vescovi, A.L. Multipotent neural stem cells reside into the rostral extension and olfactory bulb of adult rodents. J. Neurosci. 2002, 22, 437-445. [CrossRef] [PubMed]

85. Zhang, G.L.; Zhu, Z.H.; Wang, Y.Z. Neural stem cell transplantation therapy for brain ischemic stroke: Review and perspectives. World J. Stem Cells 2019, 11, 817-830. [CrossRef] [PubMed]

86. Liao, L.Y.; Lau, B.W.; Sanchez-Vidana, D.I.; Gao, Q. Exogenous neural stem cell transplantation for cerebral ischemia. Neural. Regen. Res. 2019, 14, 1129-1137. [PubMed]

87. Faigle, R.; Song, H. Signaling mechanisms regulating adult neural stem cells and neurogenesis. Biochim. Biophys. Acta 2013, 1830, 2435-2448.

88. Sirko, S.; von Holst, A.; Weber, A.; Wizenmann, A.; Theocharidis, U.; Gotz, M.; Faissner, A. Chondroitin sulfates are required for fibroblast growth factor-2-dependent proliferation and maintenance in neural stem cells and for epidermal growth factor-dependent migration of their progeny. Stem Cells 2010, 28, 775-787. [CrossRef]

89. Cooke, M.J.; Wang, Y.; Morshead, C.M.; Shoichet, M.S. Controlled epi-cortical delivery of epidermal growth factor for the stimulation of endogenous neural stem cell proliferation in stroke-injured brain. Biomaterials 2011, 32, 5688-5697. [CrossRef]

90. Bath, K.G.; Akins, M.R.; Lee, F.S. BDNF control of adult SVZ neurogenesis. Dev. Psychobiol. 2012, 54, 578-589. [CrossRef] 
91. Xu, G.; Shen, J.; Ishii, Y.; Fukuchi, M.; Dang, T.C.; Zheng, Y.; Hamashima, T.; Fujimori, T.; Tsuda, M.; Funa, K.; et al. Functional analysis of platelet-derived growth factor receptor-beta in neural stem/progenitor cells. Neuroscience 2013, 238, 195-208. [CrossRef]

92. Yokobori, S.; Saito, K.; Sasaki, K.; Kanaya, T.; Fujiki, Y.; Yamaguchi, M.; Satoh, S.; Watanabe, A.; Igarashi, Y.; Suzuki, G.; et al. Treatment for Geriatric Traumatic Brain Injury: A Nationwide Cohort Study. J. Nippon Med. Sch. 2020. [CrossRef] [PubMed]

93. Horie, N.; Hiu, T.; Nagata, I. Stem cell transplantation enhances endogenous brain repair after experimental stroke. Neurol. Med. Chir. 2015, 55, 107-112. [CrossRef] [PubMed]

94. Song, M.; Kim, Y.J.; Kim, Y.H.; Roh, J.; Kim, E.C.; Lee, H.J.; Kim, S.U.; Yoon, B.W. Long-term effects of magnetically targeted ferumoxide-labeled human neural stem cells in focal cerebral ischemia. Cell Transplant. 2015, 24, 183-190. [CrossRef] [PubMed]

95. Rosenblum, S.; Smith, T.N.; Wang, N.; Chua, J.Y.; Westbroek, E.; Wang, K.; Guzman, R. BDNF Pretreatment of Human Embryonic-Derived Neural Stem Cells Improves Cell Survival and Functional Recovery After Transplantation in Hypoxic-Ischemic Stroke. Cell Transplant. 2015, 24, 2449-2461. [CrossRef] [PubMed]

96. Cheng, Y.; Zhang, J.; Deng, L.; Johnson, N.R.; Yu, X.; Zhang, N.; Lou, T.; Zhang, Y.; Wei, X.; Chen, Z.; et al. Intravenously delivered neural stem cells migrate into ischemic brain, differentiate and improve functional recovery after transient ischemic stroke in adult rats. Int. J. Clin. Exp. Pathol. 2015, 8, 2928-2936. [PubMed]

97. Yao, H.; Gao, M.; Ma, J.; Zhang, M.; Li, S.; Wu, B.; Nie, X.; Jiao, J.; Zhao, H.; Wang, S.; et al. Transdifferentiation-Induced Neural Stem Cells Promote Recovery of Middle Cerebral Artery Stroke Rats. PLOS ONE 2015, 10, e0137211. [CrossRef]

98. Abeysinghe, H.C.; Bokhari, L.; Quigley, A.; Choolani, M.; Chan, J.; Dusting, G.J.; Crook, J.M.; Kobayashi, N.R.; Roulston, C.L. Pre-differentiation of human neural stem cells into GABAergic neurons prior to transplant results in greater repopulation of the damaged brain and accelerates functional recovery after transient ischemic stroke. Stem Cell Res. Ther. 2015, 6, 186. [CrossRef]

99. Bacigaluppi, M.; Russo, G.L.; Peruzzotti-Jametti, L.; Rossi, S.; Sandrone, S.; Butti, E.; De Ceglia, R.; Bergamaschi, A.; Motta, C.; Gallizioli, M.; et al. Neural Stem Cell Transplantation Induces Stroke Recovery by Upregulating Glutamate Transporter GLT-1 in Astrocytes. J. Neurosci. 2016, 36, 10529-10544. [CrossRef]

100. Zhu, J.D.; Wang, J.J.; Ge, G.; Kang, C.S. Effects of Noggin-Transfected Neural Stem Cells on Neural Functional Recovery and Underlying Mechanism in Rats with Cerebral Ischemia Reperfusion Injury. J. Stroke Cerebrovasc. Dis. 2017, 26, 1547-1559. [CrossRef]

101. Hou, B.; Ma, J.; Guo, X.; Ju, F.; Gao, J.; Wang, D.; Liu, J.; Li, X.; Zhang, S.; Ren, H. Exogenous Neural Stem Cells Transplantation as a Potential Therapy for Photothrombotic Ischemia Stroke in Kunming Mice Model. Mol. Neurobiol. 2017, 54, 1254-1262. [CrossRef]

102. George, P.M.; Bliss, T.M.; Hua, T.; Lee, A.; Oh, B.; Levinson, A.; Mehta, S.; Sun, G.; Steinberg, G.K. Electrical preconditioning of stem cells with a conductive polymer scaffold enhances stroke recovery. Biomaterials 2017, 142, 31-40. [CrossRef] [PubMed]

103. Tian, L.; Zhu, W.; Liu, Y.; Gong, Y.; Lv, A.; Wang, Z.; Ding, X.; Li, S.; Fu, Y.; Lin, Y.; et al. Neural Stem Cells Transfected with Leukemia Inhibitory Factor Promote Neuroprotection in a Rat Model of Cerebral Ischemia. Neurosci. Bull. 2019, 35, 901-908. [CrossRef] [PubMed]

104. Kim, J.; Shin, K.; Cha, Y.; Ban, Y.H.; Park, S.K.; Jeong, H.S.; Park, D.; Choi, E.K.; Kim, Y.B. Neuroprotective effects of human neural stem cells over-expressing choline acetyltransferase in a middle cerebral artery occlusion model. J. Chem. Neuroanat. 2020, 103, 101730. [CrossRef] [PubMed]

105. Kondori, B.J.; Asadi, M.H.; Bahadoran, H.; Yari, A.; Sarshoori, J.R. Intra-arterial transplantation of neural stem cells improve functional recovery after transient ischemic stroke in adult rats. Bratisl. Lek. Listy 2020, 121, 8-13. [CrossRef] [PubMed]

106. Wang, G.; Han, B.; Shen, L.; Wu, S.; Yang, L.; Liao, J.; Wu, F.; Li, M.; Leng, S.; Zang, F.; et al. Silencing of circular RNA HIPK2 in neural stem cells enhances functional recovery following ischaemic stroke. EBioMedicine 2020, 52, 102660. [CrossRef]

107. Daadi, M.M.; Li, Z.; Arac, A.; Grueter, B.A.; Sofilos, M.; Malenka, R.C.; Wu, J.C.; Steinberg, G.K. Molecular and magnetic resonance imaging of human embryonic stem cell-derived neural stem cell grafts in ischemic rat brain. Mol. Ther. 2009, 17, 1282-1291. [CrossRef] 
108. Yokobori, S.; Sasaki, K.; Kanaya, T.; Igarashi, Y.; Nakae, R.; Onda, H.; Masuno, T.; Suda, S.; Sowa, K.; Nakajima, M.; et al. Feasibility of Human Neural Stem Cell Transplantation for the Treatment of Acute Subdural Hematoma in a Rat Model: A Pilot Study. Front. Neurol. 2019, 10, 82. [CrossRef]

109. Horie, N.; Pereira, M.P.; Niizuma, K.; Sun, G.; Keren-Gill, H.; Encarnacion, A.; Shamloo, M.; Hamilton, S.A.; Jiang, K.; Huhn, S.; et al. Transplanted stem cell-secreted vascular endothelial growth factor effects poststroke recovery, inflammation, and vascular repair. Stem Cells 2011, 29, 274-285. [CrossRef]

110. Lee, S.T.; Chu, K.; Jung, K.H.; Kim, S.J.; Kim, D.H.; Kang, K.M.; Hong, N.H.; Kim, J.H.; Ban, J.J.; Park, H.K.; et al. Anti-inflammatory mechanism of intravascular neural stem cell transplantation in haemorrhagic stroke. Brain 2008, 131, 616-629. [CrossRef]

111. Savitz, S.I.; Dinsmore, J.; Wu, J.; Henderson, G.V.; Stieg, P.; Caplan, L.R. Neurotransplantation of fetal porcine cells in patients with basal ganglia infarcts: A preliminary safety and feasibility study. Cerebrovasc. Dis. 2005, 20, 101-107. [CrossRef]

112. Kalladka, D.; Sinden, J.; Pollock, K.; Haig, C.; McLean, J.; Smith, W.; McConnachie, A.; Santosh, C.; Bath, P.M.; Dunn, L.; et al. Human neural stem cells in patients with chronic ischaemic stroke (PISCES): A phase 1, first-in-man study. Lancet 2016, 388, 787-796. [CrossRef]

113. Wechsler, L.R.; Bates, D.; Stroemer, P.; Andrews-Zwilling, Y.S.; Aizman, I. Cell Therapy for Chronic Stroke. Stroke 2018, 49, 1066-1074. [CrossRef] [PubMed]

114. Muir, K.W.; Bulters, D.; Willmot, M.; Sprigg, N.; Dixit, A.; Ward, N.; Tyrrell, P.; Majid, A.; Dunn, L.; Bath, P.; et al. Intracerebral implantation of human neural stem cells and motor recovery after stroke: Multicentre prospective single-arm study (PISCES-2). J. Neurol. Neurosurg. Psychiatr. 2020, 91, 396-401. [CrossRef] [PubMed]

115. Takahashi, K.; Yamanaka, S. Induction of pluripotent stem cells from mouse embryonic and adult fibroblast cultures by defined factors. Cell 2006, 126, 663-676. [CrossRef]

116. Takahashi, K.; Tanabe, K.; Ohnuki, M.; Narita, M.; Ichisaka, T.; Tomoda, K.; Yamanaka, S. Induction of pluripotent stem cells from adult human fibroblasts by defined factors. Cell 2007, 131, 861-872. [CrossRef] [PubMed]

117. Chen, S.J.; Chang, C.M.; Tsai, S.K.; Chang, Y.L.; Chou, S.J.; Huang, S.S.; Tai, L.K.; Chen, Y.C.; Ku, H.H.; Li, H.Y.; et al. Functional improvement of focal cerebral ischemia injury by subdural transplantation of induced pluripotent stem cells with fibrin glue. Stem Cells Dev. 2010, 19, 1757-1767. [CrossRef]

118. Jiang, M.; Lv, L.; Ji, H.; Yang, X.; Zhu, W.; Cai, L.; Gu, X.; Chai, C.; Huang, S.; Sun, J.; et al. Induction of pluripotent stem cells transplantation therapy for ischemic stroke. Mol. Cell Biochem. 2011, 354, 67-75. [CrossRef]

119. Kawai, H.; Yamashita, T.; Ohta, Y.; Deguchi, K.; Nagotani, S.; Zhang, X.; Ikeda, Y.; Matsuura, T.; Abe, K. Tridermal tumorigenesis of induced pluripotent stem cells transplanted in ischemic brain. J. Cereb. Blood Flow Metab. 2010, 30, 1487-1493. [CrossRef]

120. Yamashita, T.; Kawai, H.; Tian, F.; Ohta, Y.; Abe, K. Tumorigenic development of induced pluripotent stem cells in ischemic mouse brain. Cell Transplant. 2011, 20, 883-891. [CrossRef]

121. Gomi, M.; Takagi, Y.; Morizane, A.; Doi, D.; Nishimura, M.; Miyamoto, S.; Takahashi, J. Functional recovery of the murine brain ischemia model using human induced pluripotent stem cell-derived telencephalic progenitors. Brain Res. 2012, 1459, 52-60. [CrossRef]

122. Oki, K.; Tatarishvili, J.; Wood, J.; Koch, P.; Wattananit, S.; Mine, Y.; Monni, E.; Tornero, D.; Ahlenius, H.; Ladewig, J.; et al. Human-induced pluripotent stem cells form functional neurons and improve recovery after grafting in stroke-damaged brain. Stem Cells 2012, 30, 1120-1133. [CrossRef] [PubMed]

123. Polentes, J.; Jendelova, P.; Cailleret, M.; Braun, H.; Romanyuk, N.; Tropel, P.; Brenot, M.; Itier, V.; Seminatore, C.; Baldauf, K.; et al. Human induced pluripotent stem cells improve stroke outcome and reduce secondary degeneration in the recipient brain. Cell Transplant. 2012, 21, 2587-2602. [CrossRef] [PubMed]

124. Chang, D.J.; Lee, N.; Park, I.H.; Choi, C.; Jeon, I.; Kwon, J.; Oh, S.H.; Shin, D.A.; Do, J.T.; Lee, D.R.; et al. Therapeutic potential of human induced pluripotent stem cells in experimental stroke. Cell Transplant. 2013, 22, 1427-1440. [CrossRef]

125. Jensen, M.B.; Yan, H.; Krishnaney-Davison, R.; Al Sawaf, A.; Zhang, S.C. Survival and differentiation of transplanted neural stem cells derived from human induced pluripotent stem cells in a rat stroke model. J. Stroke Cerebrovasc. Dis. 2013, 22, 304-308. [CrossRef] 
126. Mohamad, O.; Drury-Stewart, D.; Song, M.; Faulkner, B.; Chen, D.; Yu, S.P.; Wei, L. Vector-free and transgene-free human iPS cells differentiate into functional neurons and enhance functional recovery after ischemic stroke in mice. PLoS ONE 2013, 8, e64160. [CrossRef]

127. Yuan, T.; Liao, W.; Feng, N.H.; Lou, Y.L.; Niu, X.; Zhang, A.J.; Wang, Y.; Deng, Z.F. Human induced pluripotent stem cell-derived neural stem cells survive, migrate, differentiate, and improve neurologic function in a rat model of middle cerebral artery occlusion. Stem Cell Res. Ther. 2013, 4, 73. [CrossRef] [PubMed]

128. Tornero, D.; Wattananit, S.; Grønning Madsen, M.; Koch, P.; Wood, J.; Tatarishvili, J.; Mine, Y.; Ge, R.; Monni, E.; Devaraju, K.; et al. Human induced pluripotent stem cell-derived cortical neurons integrate in stroke-injured cortex and improve functional recovery. Brain 2013, 136, 3561-3577. [CrossRef] [PubMed]

129. Tornero, D.; Tsupykov, O.; Granmo, M.; Rodriguez, C.; Grønning-Hansen, M.; Thelin, J.; Smozhanik, E.; Laterza, C.; Wattananit, S.; Ge, R.; et al. Synaptic inputs from stroke-injured brain to grafted human stem cell-derived neurons activated by sensory stimuli. Brain 2017, 140, 692-706. [CrossRef]

130. Tatarishvili, J.; Oki, K.; Monni, E.; Koch, P.; Memanishvili, T.; Buga, A.M.; Verma, V.; Popa-Wagner, A.; Brüstle, O.; Lindvall, O.; et al. Human induced pluripotent stem cells improve recovery in stroke-injured aged rats. Restor. Neurol. Neurosci. 2014, 32, 547-558. [CrossRef]

131. Payne, S.L.; Anandakumaran, P.N.; Varga, B.V.; Morshead, C.M.; Nagy, A.; Shoichet, M.S. In Vitro Maturation of Human iPSC-Derived Neuroepithelial Cells Influences Transplant Survival in the Stroke-Injured Rat Brain. Tissue Eng. Part A 2018, 24, 351-360. [CrossRef]

132. Jensen, M.B.; Jager, L.D.; Cohen, L.K.; Kwok, S.S.; Kwon, J.M.; Hall, C.A.; Heilingoetter, C. Effects of neural differentiation maturity status of human induced pluripotent stem cells prior to grafting in a subcortical ischemic stroke model. Neurol. Psychiatr. Brain Res. 2016, 22, 178-182. [CrossRef] [PubMed]

133. Laterza, C.; Uoshima, N.; Tornero, D.; Wilhelmsson, U.; Stokowska, A.; Ge, R.; Pekny, M.; Lindvall, O.; Kokaia, Z. Attenuation of reactive gliosis in stroke-injured mouse brain does not affect neurogenesis from grafted human iPSC-derived neural progenitors. PLoS ONE 2018, 13, e0192118. [CrossRef] [PubMed]

134. Baker, E.W.; Platt, S.R.; Lau, V.W.; Grace, H.E.; Holmes, S.P.; Wang, L.; Duberstein, K.J.; Howerth, E.W.; Kinder, H.A.; Stice, S.L.; et al. Induced Pluripotent Stem Cell-Derived Neural Stem Cell Therapy Enhances Recovery in an Ischemic Stroke Pig Model. Sci. Rep. 2017, 7, 10075. [CrossRef]

135. Lau, V.W.; Platt, S.R.; Grace, H.E.; Baker, E.W.; West, F.D. Human iNPC therapy leads to improvement in functional neurologic outcomes in a pig ischemic stroke model. Brain Behav. 2018, 8, e00972. [CrossRef]

136. Ortuno-Costela, M.D.C.; Cerrada, V.; Garcia-Lopez, M.; Gallardo, M.E. The Challenge of Bringing iPSCs to the Patient. Int. J. Mol. Sci. 2019, 20, 6305. [CrossRef] [PubMed]

137. de Rham, C.; Villard, J. Potential and limitation of HLA-based banking of human pluripotent stem cells for cell therapy. J. Immunol. Res. 2014, 2014, 518135. [CrossRef] [PubMed]

138. Kurozumi, K.; Nakamura, K.; Tamiya, T.; Kawano, Y.; Ishii, K.; Kobune, M.; Hirai, S.; Uchida, H.; Sasaki, K.; Ito, Y.; et al. Mesenchymal stem cells that produce neurotrophic factors reduce ischemic damage in the rat middle cerebral artery occlusion model. Mol. Ther. 2005, 11, 96-104. [CrossRef] [PubMed]

139. Schabitz, W.R.; Sommer, C.; Zoder, W.; Kiessling, M.; Schwaninger, M.; Schwab, S. Intravenous Brain-Derived Neurotrophic Factor Reduces Infarct Size and Counterregulates Bax and Bcl-2 Expression After Temporary Focal Cerebral Ischemia. Stroke 2000, 31, 2212-2217. [CrossRef]

140. Ding, H.; Chen, J.; Su, M.; Lin, Z.; Zhan, H.; Yang, F.; Li, W.; Xie, J.; Huang, Y.; Liu, X.; et al. BDNF promotes activation of astrocytes and microglia contributing to neuroinflammation and mechanical allodynia in cyclophosphamide-induced cystitis. J. Neuroinflamm. 2020, 17, 19. [CrossRef]

141. Hira, K.; Ueno, Y.; Tanaka, R.; Miyamoto, N.; Yamashiro, K.; Inaba, T.; Urabe, T.; Okano, H.; Hattori, N. Astrocyte-Derived Exosomes Treated With a Semaphorin 3A Inhibitor Enhance Stroke Recovery via Prostaglandin D2 Synthase. Stroke 2018, 49, 2483-2494. [CrossRef]

142. Curcio, M.; Salazar, I.L.; Inacio, A.R.; Duarte, E.P.; Canzoniero, L.M.; Duarte, C.B. Brain ischemia downregulates the neuroprotective GDNF-Ret signaling by a calpain-dependent mechanism in cultured hippocampal neurons. Cell Death Dis. 2015, 6, e1645. [CrossRef]

143. Ding, J.; Cheng, Y.; Gao, S.; Chen, J. Effects of nerve growth factor and Noggin-modified bone marrow stromal cells on stroke in rats. J. Neurosci. Res. 2011, 89, 222-230. [CrossRef] [PubMed]

144. Tondreau, T.; Dejeneffe, M.; Meuleman, N.; Stamatopoulos, B.; Delforge, A.; Martiat, P.; Bron, D.; Lagneaux, L. Gene expression pattern of functional neuronal cells derived from human bone marrow mesenchymal stromal cells. BMC Genom. 2008, 9, 166. [CrossRef] [PubMed] 
145. Lee, H.J.; Kim, K.S.; Park, I.H.; Kim, S.U. Human neural stem cells over-expressing VEGF provide neuroprotection, angiogenesis and functional recovery in mouse stroke model. PLoS ONE 2007, 2, e156. [CrossRef] [PubMed]

146. Zhao, M.Z.; Nonoguchi, N.; Ikeda, N.; Watanabe, T.; Furutama, D.; Miyazawa, D.; Funakoshi, H.; Kajimoto, Y.; Nakamura, T.; Dezawa, M.; et al. Novel therapeutic strategy for stroke in rats by bone marrow stromal cells and ex vivo HGF gene transfer with HSV-1 vector. J. Cereb. Blood Flow Metab. 2006, 26, 1176-1188. [CrossRef] [PubMed]

147. Liu, H.; Honmou, O.; Harada, K.; Nakamura, K.; Houkin, K.; Hamada, H.; Kocsis, J.D. Neuroprotection by PIGF gene-modified human mesenchymal stem cells after cerebral ischaemia. Brain 2006, 129, 2734-2745. [CrossRef] [PubMed]

148. Toyama, K.; Honmou, O.; Harada, K.; Suzuki, J.; Houkin, K.; Hamada, H.; Kocsis, J.D. Therapeutic benefits of angiogenetic gene-modified human mesenchymal stem cells after cerebral ischemia. Exp. Neurol. 2009, 216, 47-55. [CrossRef]

149. Ruan, L.; Wang, B.; ZhuGe, Q.; Jin, K. Coupling of neurogenesis and angiogenesis after ischemic stroke. Brain Res. 2015, 1623, 166-173. [CrossRef]

150. Cho, G.W.; Koh, S.H.; Kim, M.H.; Yoo, A.R.; Noh, M.Y.; Oh, S.; Kim, S.H. The neuroprotective effect of erythropoietin-transduced human mesenchymal stromal cells in an animal model of ischemic stroke. Brain Res. 2010, 1353, 1-13. [CrossRef]

151. Brines, M.L.; Ghezzi, P.; Keenan, S.; Agnello, D.; de Lanerolle, N.C.; Cerami, C.; Itri, L.M.; Cerami, A. Erythropoietin Crosses the Blood-Brain Barrier to Protect Against Experimental Brain Injury. Proc. Natl. Acad. Sci. USA 2000, 97, 10526-10531. [CrossRef]

152. Zhou, Z.; Peng, X.; Insolera, R.; Fink, D.J.; Mata, M. Interleukin-10 provides direct trophic support to neurons. J. Neurochem. 2009, 110, 1617-1627. [CrossRef] [PubMed]

153. Nomoto, T.; Okada, T.; Shimazaki, K.; Yoshioka, T.; Nonaka-Sarukawa, M.; Ito, T.; Takeuchi, K.; Katsura, K.I.; Mizukami, H.; Kume, A.; et al. Systemic delivery of IL-10 by an AAV vector prevents vascular remodeling and end-organ damage in stroke-prone spontaneously hypertensive rat. Gene Ther. 2009, 16, 383-391. [CrossRef] [PubMed]

154. Lu, H.; Liu, X.; Zhang, N.; Zhu, X.; Liang, H.; Sun, L.; Cheng, Y. Neuroprotective Effects of Brain-Derived Neurotrophic Factor and Noggin-Modified Bone Mesenchymal Stem Cells in Focal Cerebral Ischemia in Rats. J. Stroke Cerebrovasc. Dis. 2016, 25, 410-418. [CrossRef] [PubMed] 